\title{
A case study of artificial reefs as a potential tool for maintaining artisanal fisheries in the French Mediterranean Sea
}

\author{
Anne Tessier ${ }^{1,2, *}$, Marion Verdoit-Jarraya ${ }^{2,3}$, Sylvain Blouet $^{4}$, Nicolas Dalias ${ }^{1}$, \\ Philippe Lenfant ${ }^{2,3}$ \\ ${ }^{1}$ SEANEO, 11 Rue Louis Esparre, 66100, Perpignan, France \\ ${ }^{2}$ Université de Perpignan Via Domitia, Centre de Formation et de Recherche sur les Environnements Méditerranéens, \\ UMR 5110, 52 Avenue Paul Alduy, 66860, Perpignan, France \\ ${ }^{3}$ CNRS, Centre de Formation et de Recherche sur les Environnements Méditerranéens, UMR 5110, 52 Avenue Paul Alduy \\ 66860, Perpignan, France \\ ${ }^{4}$ Mairie d'Agde, Direction Gestion du milieu marin, 34300, Agde, France
}

\begin{abstract}
The aim of this study was to obtain information allowing an initial assessment of the potential of French Mediterranean artificial reefs (ARs) as a management tool to aid artisanal fishermen. The study focuses on 3 ARs located along the Gulf of Lion coastline in the French Mediterranean Sea. At the end of spring 2012, experimental fishing with trammel nets was conducted at ARs and natural rocky areas (NRs) at various distances from the ARs/NRs (0,300 and $900 \mathrm{~m})$. The yields of fish and invertebrates were analyzed at the AR sites to identify significant changes along a distance gradient and to determine whether there was a significant difference between ARs and NRs. The AR yields of species preferring rocky substrates were generally higher between 0 and $300 \mathrm{~m}$ from the ARs than beyond $300 \mathrm{~m}$, whereas the yields of species preferring sandy substrates or of invertebrates did not differ between 0 and $900 \mathrm{~m}$ from the ARs. Furthermore, the AR yields were equal to the NR yields or were between 1.5- and 1.8-fold higher than the NR yields. Overall, this study indicates that success varied by species, fishing locality and distance from the reef. ARs could be a potentially effective tool for enhancing artisanal fishing along the French Mediterranean coasts. However, it would be necessary to establish management measures to avoid overexploitation. For instance, in terms of the configuration of the AR areas in a given locality, a notake area could be established within a radius of $300 \mathrm{~m}$ around the ARs.
\end{abstract}

KEY WORDS: Fish assemblage $\cdot$ Soleidae $\cdot$ Trammel net $\cdot$ Catches $\cdot$ Gulf of Lion Resale or republication not permitted without written consent of the publisher

\section{INTRODUCTION}

In the Mediterranean Sea, artisanal fishing is a principal element of the coastal economy and provides important food resources, representing approximately $80 \%$ of the Mediterranean fleet in terms of the number of vessels (32950 vessels) (Forcada et al. 2010) and generating $>100000$ jobs while simultaneously playing a major cultural role (FAO 2010, Forcada et al. 2010). Artisanal fishing is often viewed as coastal fishing with boats that are usually $<12 \mathrm{~m}$ in length in an area located on the continental shelf ( 0 to $200 \mathrm{~m}$ water depth) only a few hours from the base harbor (Colloca et al. 2004). Artisanal fishing involves a wide range of techniques, fishing gears and target species, including fish and mollusks (Forcada et al. 2010).

According to the French Research Institute for Exploitation of the Sea (IFREMER), French artisanal fishing vessels represented approximately $90 \%$ of the 
French Mediterranean coastal fishing fleet (1545 vessels) in 2010. However, French Mediterranean artisanal fishing has been declining since the end of the 1980s. Between 1986 and 1996, the number of vessels in the artisanal fleet decreased by $50 \%$ (Guillou \& Crespi 1999) and fell a further $8 \%$ between 1996 and 2010 (Guillou \& Crespi 1999, IFREMER 2012).

This decline in France and in other Mediterranean countries is a notable consequence of increased fishing effort in terms of the engine power and increased capacity of fishing equipment for both artisanal and industrial fisheries. This increased effort has caused the overexploitation of stocks of target species (Pinnegar \& Polunin 2004). Furthermore, other anthropogenic pressures, such as sewage pollution, littoral construction and tourism, have also degraded littoral ecosystems (Gómez et al. 2006).

Governments emphasize the preservation of artisanal fishing because of its sustainability, due to its use of fishing techniques that are selective in terms of target species and capture size (Forcada et al. 2010). Furthermore, artisanal fishing causes less damage to the seabed and consumes less fuel than industrial or semi-industrial fishing (Forcada et al. 2010). In this context, local authorities have deployed artificial reefs (ARs) along the French Mediterranean coast since the 1980s, notably along the LanguedocRoussillon coast (Ody 1990, Barnabé et al. 2000), with the aim of sustaining artisanal fishing. ARs are currently considered to be a possible tool to achieve this objective, along with other measures, such as the establishment of marine protected areas.

ARs are submerged structures that are deliberately placed on the sea bottom to influence physical, biological and/or socio-economic processes (Seaman 2000). ARs are employed worldwide for several purposes, notably to impede trawling and/or to enhance fish production in an area by providing hard substrata for benthic and fish communities (Seaman 2000). In the French Mediterranean, the main objective of the use of ARs is to sustain artisanal fishing by increasing the catches of commercial species in terms of number and biomass (Barnabé et al. 2000). The principal objectives of AR deployment in the studied area were to generate new habitats similar to natural rocky areas (NRs) and to protect target species stocks on the sandy bottom from illegal trawling within the 3 nautical mile ( $\mathrm{nmi} ; 5.55 \mathrm{~km}$ ) coastal fishing limit (Barnabé et al. 2000). Thorough studies of ARs are necessary to determine their ability to fully support these objectives.

Studies have shown beneficial effects of ARs on fishing yields worldwide and specifically in the
Mediterranean Sea (Bombace et al. 1994, D'Cruz et al. 1994, Santos \& Monteiro 2007). The studies indicate that ARs attract fish of commercial interest (D'Cruz et al. 1994, Zalmon et al. 2002). Furthermore, species richness and capture per unit effort (CPUE) in terms of the number of individuals or biomass are higher in ARs than in natural rocky areas (Bombace et al. 1994, Fabi \& Fiorentini 1994, Zalmon et al. 2002). However, several studies have shown potential negative effects of ARs on fish stocks. Indeed, ARs have an attractive effect on fish in certain cases (Matthews 1985, Pickering \& Whitmarsh 1997); when used by artisanal fishermen, they may facilitate access to the targeted resource, leading to the potential overexploitation of fish stocks (Grossman et al. 1997, Osenberg et al. 2002). In France, very few studies have examined ARs with respect to artisanal fishing, and data on landings per unit net (trammel or gillnet) show no differences in biomass between ARs and NRs (Koeck et al. 2011). A few studies have examined the responses of fish and invertebrate assemblages to ARs by experimental fishing along a distance gradient and via acoustic techniques (Gerlotto et al. 1989, Stanley \& Wilson 2000, Fabi \& Sala 2002, Løkkeborg et al. 2002, Dos Santos et al. 2010). The results indicate a decrease in species richness, density and biomass with increased distance from ARs.

In general, studies of ARs from a fisheries perspective address all fish and invertebrates of commercial interest. Studies focused on 1 or 2 species are less numerous, and those studies have focused exclusively on species that inhabit rocky substrates (Polovina 1991, Leitão et al. 2009, Dos Santos et al. 2010), fish that prefer sandy bottoms or invertebrates of commercial interest (Polovina \& Sakai 1989). However, ARs can also have an effect on sandy-mud bottom species of commercial interest by obstructing illegal trawling in the area of deployment, thus protecting the stocks of these species against overexploitation. Nevertheless, very few studies have focused on the response of species in this category (Walton 1982), such as fish species in the family Soleidae or invertebrate species in the family Muricidae. Soleidae and Bolinus brandaris (a muricid gastropod) are of commercial interest in the Mediterranean Sea, particularly along the French Mediterranean coastlines (Campillo 1992, Martín et al. 1995, Vasconcelos et al. 2008).

The first aim of this study was to improve the very limited knowledge of the effect of ARs of the Languedoc-Roussillon coast on species assemblages by providing a quantitative description of catches produced by experimental fishing from NR and AR sites at 3 localities of local interest to fishing and resource 
managers. The study hypotheses were that (1) ARs create a hard bottom and attract fish which prefer rocky bottoms, thus providing sites for fishermen similar to NRs, (2) catches of fish preferring rocky bottoms decrease as the distance from the AR increases, and (3) catches of fish preferring sandy bottoms increase as the distance to the AR increases. The second aim was to provide information allowing an initial assessment of the extent to which the ARs of the Languedoc-Roussillon coast benefit local artisanal fisheries.

\section{MATERIALS AND METHODS}

\section{Study locations and sites}

The study focused on 2 types of sites, artificial reefs (AR) and natural rocky areas (NRs), at 3 localities ('Locality' variable) along the Gulf of Lion coast (northwestern Mediterranean Sea): Agde, Valras and Leucate-Barcarès (Fig. 1).

The Agde NR (ANR) is a basaltic rock formation that extends from a depth of $8 \mathrm{~m}$ to a depth of $40 \mathrm{~m}$ (Fig. 1). Coralligenous areas are present at the $15 \mathrm{~m}$ isobath in an area of marked relief (height $\sim 1.5 \mathrm{~m}$ ). The Agde ARs were deployed in 1985, 1992, 1995 and 2009 on a flat and homogeneous sandy-mud bottom at depths between 10 and $35 \mathrm{~m}$ and $1 \mathrm{nmi}(1.85 \mathrm{~km})$ from the coast (Fig. 1). The AR sites were organized into the following 6 zones: 3 composed exclusively of pipes, 1 'Bonna' type reef, 1 'Comin' type reef and 2 zones with steel cages (Fig. 2). The distance between 2 modules (pipe or steel cage) in each zone is $\sim 200 \mathrm{~m}$. AR sites surround the NR area. Our AR study site was located east of the NR area at a minimum distance of $0.5 \mathrm{~km}$ and is composed of pipes deployed in 2009 (Fig. 1, Table 1).

The Valras NR (VNR) is located $17 \mathrm{~km}$ WSW of Agde and faces the mouth of the Aude River (Fig. 1). This rocky area extends from depths of 18 to $22 \mathrm{~m}$ and is $2 \mathrm{nmi}$ $(3.7 \mathrm{~km})$ from the coast. This natural site is a rocky outcrop with low relief $(0.5 \mathrm{~m})$. Some slabs of coralligenous concretions are silted. The Valras ARs were deployed in 2006 in 2 zones on a flat and homogeneous sandy-

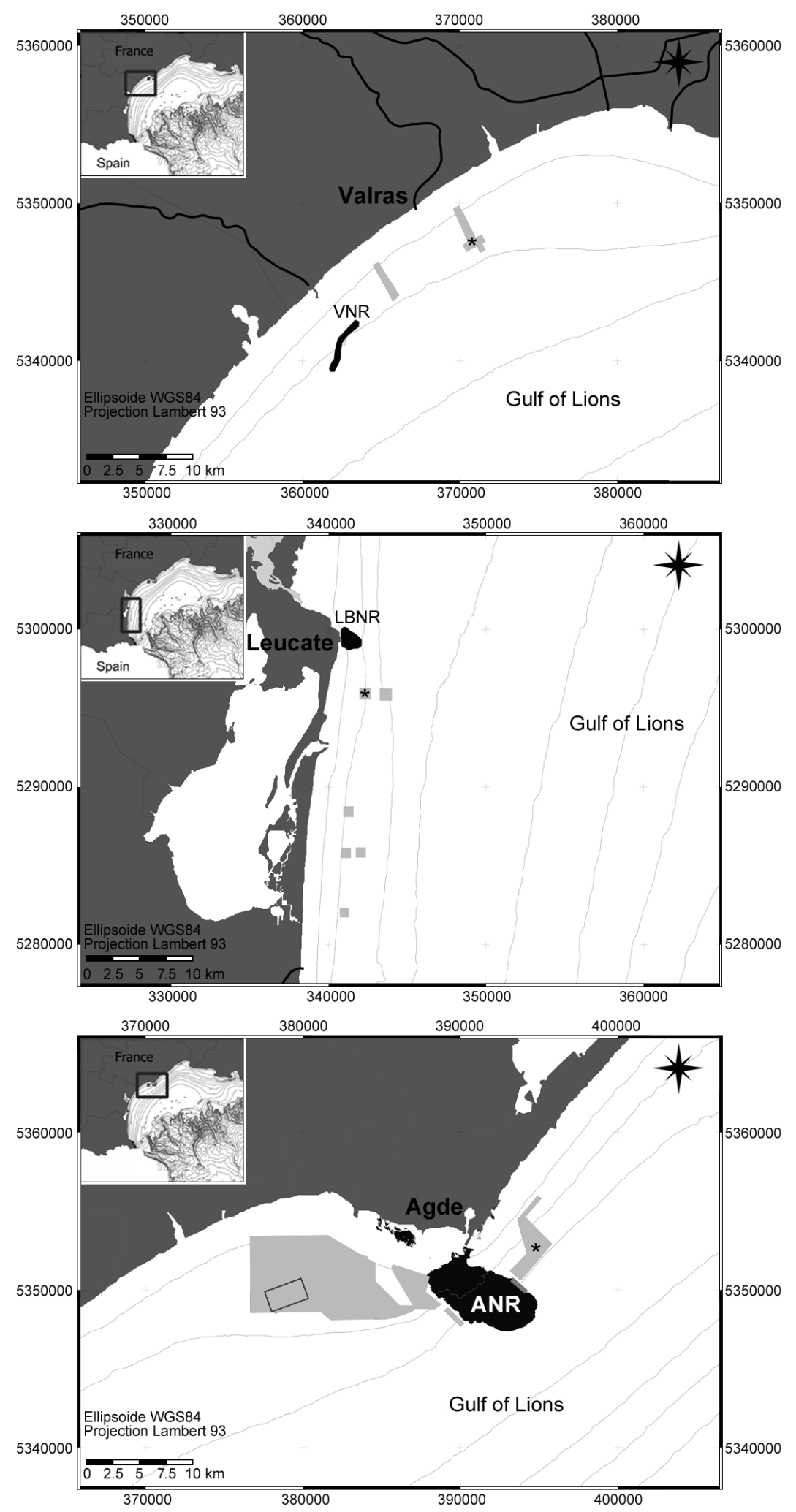

Fig. 1. Map showing the 3 study localities: Agde (A), Valras (V) and Leucate-Barcarès (LB) along the French coast of the Gulf of Lion and their 2 associated sites. Natural rocky areas (NR) are black, and artificial reef sites (AR) are grey; *: AR studied 

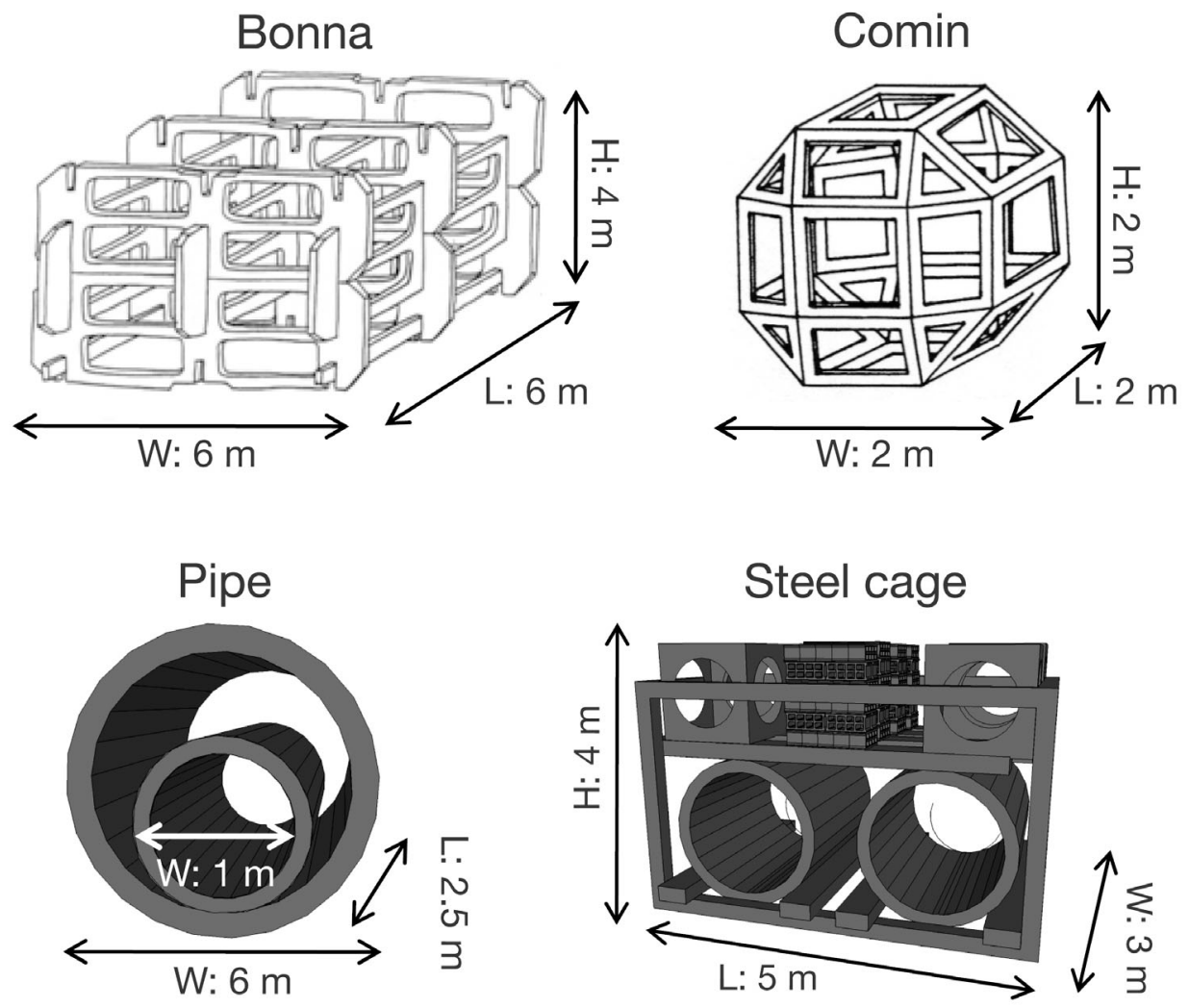

\section{Concrete box}
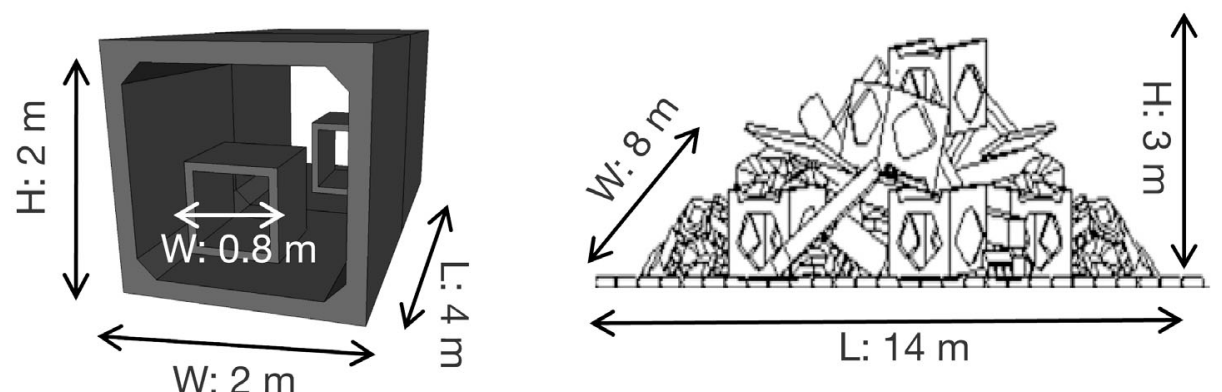

Fig. 2. Different types of modules deployed at the studied artificial reef sites

mud bottom between depths of 9 and $25 \mathrm{~m}, 0.5 \mathrm{nmi}$ $(0.93 \mathrm{~km})$ from the coast (Fig. 1). The 2 zones are composed of pipes, and the more northerly zone relative to the NR is also composed of steel cages (Fig. 2). In each zone, the distance between 2 units (pipe or steel cage) is $\sim 50 \mathrm{~m}$. The AR site of this study is located $3 \mathrm{nmi}(5.55 \mathrm{~km})$ north of the nearest NR area (Fig. 1, Table 1).

The NR area of Leucate-Barcarès (LBNR) is located $55 \mathrm{~km} \mathrm{SSW}$ of Agde and $40 \mathrm{~km} \mathrm{SSW}$ of Valras and extends from depths of 0 to $20 \mathrm{~m}$ (Fig. 1). This NR area forms a plateau at depths ranging from 0 to $12 \mathrm{~m}$ and extends beyond this depth to a zone of rock slides. Coralligenous concretions cover the rock in several places. The Leucate-Barcarès ARs were deployed in 2004 in 6 zones (Fig. 1) on a flat and homogeneous sandy-mud bottom between depths of 15 and $30 \mathrm{~m}, 0.5 \mathrm{nmi}(0.93 \mathrm{~km})$ from the coast (Koeck et al. 2011). Each zone is composed of pipes, concrete boxes and chaotic heaps (Fig. 2). The chaotic heaps are unorganized arrangements of pipes, cubes with each side open, breeze-blocks, pieces of rock and beams. The units are spaced $50 \mathrm{~m}$ apart (Koeck et al. 2011). The study site was the zone closest $(1 \mathrm{nmi}$ or $1.85 \mathrm{~km}$ ) to the NR area (Fig. 1, Table 1). 
Table 1. Characteristics of sampling sites. NR: natural rocky area; AR: artificial reef

\begin{tabular}{|lccccccc|}
\hline Locality & $\begin{array}{c}\text { Type } \\
\text { of site }\end{array}$ & $\begin{array}{c}\text { Date of } \\
\text { deployment }\end{array}$ & $\begin{array}{c}\text { Surface of } \\
\text { reef area } \\
\text { studied (ha) }\end{array}$ & $\begin{array}{c}\text { Distance } \\
\text { from NR } \\
\text { (km) }\end{array}$ & $\begin{array}{c}\text { Type of AR } \\
\text { modules }\end{array}$ & $\begin{array}{c}\text { Sampling } \\
\text { depth } \\
\text { (m) }\end{array}$ & $\begin{array}{c}\text { Distance } \\
\text { between 2 } \\
\text { modules (m) }\end{array}$ \\
\hline Agde & NR & - & 1149 & - & - & 12 & - \\
Agde & AR & 2009 & 239 & 0.4 & Pipes & 12 & 200 \\
Valras & NR & - & 0.6 & - & - & 20 & - \\
Valras & AR & 2006 & 0.7 & 4.5 & Pipes, steel cages & 20 & 50 \\
Leucate-Barcarès & NR & - & 5 & - & - & Pipes, concrete & 20 \\
Leucate-Barcarès & AR & 2004 & 1.2 & 1.5 & & boxes, chaotic heaps & 50 \\
& & & & & & & \\
\hline
\end{tabular}

\section{Data collection}

Between April and June 2012, each station at the AR and NR sites was sampled 10 times by experimental fishing with a bottom trammel net that was $300 \mathrm{~m}$ long and $1.7 \mathrm{~m}$ in height, with a $45 \mathrm{~mm}$ inner mesh and a $250 \mathrm{~mm}$ external mesh, a size used by the majority of local fishermen. The trammel net does not provide a reliable sample of the catchable biomass, species richness and diversity of fish present because it is selective based on its position in the water column and its mesh size (Fabi \& Fiorentini 1994), however, it is one of the most effective fish sampling techniques (Santos \& Monteiro 1997), and potential biases were considered in the study. The end of spring was chosen for many reasons. At this time of the year, it is easier for the fishermen to position the nets in the sea due to favourable climatic conditions and they still have time to participate in experimental fishing. This is not the case in the summer, when their activity is at its peak due to the presence of tourists. Furthermore, at the end of spring and during the summer, species densities are higher in the coastal zones and particularly on ARs (Relini et al. 1994). The interpretations of the results will be essentially limited to this study and are only valid for the end of spring because fish communities change with the seasons.

The relationship of fishing yield and species richness to distance from the AR was also experimentally assessed. For this purpose, nets were positioned parallel to the coast at the AR and NR sites at multiple distances ('Station' variable): $0 \mathrm{~m}$ (closest to the site, Near), 300 to $600 \mathrm{~m}$ (Medium) and 900 to $1200 \mathrm{~m}$ (Far). The objective was to predict whether the fishing yield of most species and species richness would vary with the distance from the reef. The nets were set for $10 \mathrm{~h}$ at night. The trammel net is efficient at night, and this time is the same as that generally used by local fishermen. The AR and NR sites for each locality were sampled simultaneously and, whenever possible, simultaneously among localities to reduce variability due to weather and sea conditions. Nets were deployed at a depth of $19 \mathrm{~m}$ at Valras and Leucate-Barcarès and at a depth of $12 \mathrm{~m}$ at Agde due to the topography of the sites.

All specimens caught were measured to the nearest millimeter $(\mathrm{mm})$ and weighed to the nearest gram (g) (Bombace et al. 1994). For Bolinus brandaris, a gastropod of commercial interest in the area, the total number of individuals and the total weight were recorded, and subsamples of 50 random individuals were measured and weighed individually.

\section{Data analysis}

In most cases, standardization of the data in this study was not necessary as all trammel nets were similar and, in good climatic conditions, fishing time was fixed at $10 \mathrm{~h}$. However, in 4 cases it was necessary to apply a standardization procedure because the fishing time exceeded $10 \mathrm{~h}$. In these cases, the following equation was used: number of fish $300 \mathrm{~m}^{-1}$ night $^{-1}(10 \mathrm{~h})=($ total number of captured fish per $300 \mathrm{~m}$ per total fishing time $\times 10 \mathrm{~h}$ )/fishing time of the sampling night. The same equation of standardization was used for the other studied variables.

\section{Spatial differences in community structure and substratum affinities}

A nonmetric multidimensional scaling plot (nMDS), combined with a hierarchical cluster analysis, was created using center-reduced data $\left(Z_{i}=\left[X_{i}-X_{\text {mean }}\right] /\right.$ $\sigma_{i} X$ is the observed value, and $i$ is the sample number) on fish and invertebrate CPUEs (number of individuals $300 \mathrm{~m}^{-1}$ night $^{-1}$ ). The term 'night' refers to $10 \mathrm{~h}$ of fishing with the nets. 
Bray-Curtis similarity coefficients were used to detect variation in species composition based on the factors (Site $\times$ Station) for each locality. Similarity analyses (ANOSIM) of Bray-Curtis similarity coefficients between groups of replicates for each factor were calculated to test for differences in composition. A similarity percentage analysis (SIMPER) was then performed to identify the species that contributed most to community structure dissimilarities. These analyses were conducted with Primer 6 software.

A multiple correspondence factorial analysis (MCA) was also conducted. This analysis considered the total number of species caught for the following 3 categorical variables: Locality, with 3 categories (Agde, Valras and Leucate-Barcarès); the substratum Choice (Choice), with 5 categories (no choice $[N]$, soft substrate such as mud/sand [S], rocky [R], vegetated substrate such as seaweed [V] and rocky and vegetated substrate [RV]); and a variable that crossed the 2 variables Site and Station (named Site-Station) with the 6 previously defined categories (AR-Near, AR-Medium, AR-Far, NR-Near, NR-Medium and NR-Far). Factorial axes were then characterized by computing test values. Test values were considered to be statistically significant if their absolute value was $>2$ (Lebart et al. 1984). Moreover, a higher absolute value of a test value associated with a category was considered to indicate a greater significance for that category.

\section{Quantitative and qualitative differences}

The differences in species richness and CPUE in terms of the number of individuals and weight for both fish and invertebrates among the sites and stations were tested using either a 2-way ANOVA with or without 9999 permutations or a ScheirerRay-Hare's test depending on the conditions applying at each locality (Sokal \& Rohlf 1995, Anderson \& Legendre 1999). An analysis based on permutations tests whether there is a significant difference in CPUE, for example, among the sites and stations by rearranging the individual CPUE values for the sites and stations $\mathrm{n}$ times (in this case, $\mathrm{n}=9999$; the values were rearranged 9999 times and tested each time). Whenever these tests indicated a significant difference, a post hoc or an a posteriori test was used to identify the modalities of the factor associated with the variation in the response variable (Tukey's honestly significant difference, $t$-test with 9999 permutations or Mann-Whitney test).

\section{Differences in size structure}

The number of fish for all species was also determined by size class. Allocation to size class was performed for each individual by species. A fish was classified as 'Small' if it was less than one-third of the maximum total length (the reference size), 'Medium' when between one-third and two-thirds of the reference size and 'Large' when greater than two-thirds of the reference size (Harmelin-Vivien et al. 1985). The reference size was chosen according to Louisy (2002). The species richness assessment included all species. For the other variables, however, only species of economic interest were considered (Table 2). For fish, the focus was on the Soleidae family (2 species: Solea solea and Pegusa theophilus), which has high economic value.

For invertebrates, the analyses concentrated on Bolinus brandaris because it predominated in terms of the number of individuals caught compared to other species. This species usually represented $>90 \%$ of the invertebrates caught at each locality. A size class analysis was not performed for this species because the analysis of size required exact measurements of individual sizes. The analyses were conducted using R 2.9.0 software, and all tests were considered significant at $\mathrm{p}<0.05$.

This study is based on pseudoreplicates. This design is often used in marine ecology due to field constraints (Heffner et al. 1996). In this study, the pseudoreplicates permitted intra- and inter-locale standardization for experimental fishing in terms of distance to the ARs and similar depths. The problem with pseudoreplicates is their lack of independence, which decreases the variability of the collected data and can result in erroneous conclusions. However, to minimize this bias, fishing was performed on several different days (Millar \& Anderson 2004) and catches were highly variable between days.

\section{RESULTS}

A total of 1227 fish representing 40 species in 19 families with a total weight of $243.34 \mathrm{~kg}$ and a total of 3230 invertebrates representing 21 species in 17 families, predominantly Boninus brandaris $(66.14 \mathrm{~kg})$, were caught (Table 2). The number of species caught was higher in NRs than in ARs, except for at Agde, which had the opposite pattern. 
Table 2. Species identified at each locality and habitat. Total species richness is indicated in brackets. NR: natural rocky area; AR: artificial reef; SC: substrate choice; N: no choice; R: rocky/coralligenous substratum; S: soft substratum such as mud/sand; V: vegetated substrate such as seaweed; RV: rocky and vegetated substrate; CI: of commercial interest in Languedoc-Roussillon; $(-)$ not observed

\begin{tabular}{|c|c|c|c|c|c|c|c|c|c|}
\hline Family & Species & $\mathrm{SC}$ & CI & $\begin{array}{r}\text { Agd } \\
\text { NR (19) }\end{array}$ & $\begin{array}{l}\text { e (31) } \\
\text { AR (29) }\end{array}$ & $\begin{array}{r}\text { Valr } \\
\text { NR (23) }\end{array}$ & $\begin{array}{l}\text { as }(27) \\
\text { AR (20) }\end{array}$ & \multicolumn{2}{|c|}{$\begin{array}{l}\text { Leucate-Barcarès (53) } \\
\text { NR (43) AR (37) }\end{array}$} \\
\hline \multicolumn{10}{|l|}{ (A) Fish species } \\
\hline Sparidae & Boops boops (Linnaeus, 1758) & $\mathrm{N}$ & No & _ & _ & - & $\mathrm{X}$ & - & - \\
\hline Mugilidae & Liza ramada (Risso, 1810) & $\mathrm{N}$ & Yes & - & $\mathrm{X}$ & - & - & - & - \\
\hline Merluccidae & Merluccius merluccius (Linnaeus, 1758) & $\mathrm{N}$ & Yes & - & - & - & - & $\mathrm{X}$ & $\mathrm{X}$ \\
\hline Scombridae & Scomber scombrus Linnaeus, 1758 & $\mathrm{~N}$ & Yes & - & $\mathrm{X}$ & - & - & - & - \\
\hline Sparidae & Sparus aurata Linnaeus, 1758 & $\mathrm{~N}$ & Yes & - & $\mathrm{X}$ & _ & $\mathrm{X}$ & $\mathrm{X}$ & - \\
\hline Sparidae & Spondyliosoma cantharus (Linnaeus, 1758) & $\mathrm{N}$ & Yes & _- & - & _- & - & - & $\mathrm{X}$ \\
\hline Gadidae & Trisopterus luscus capelanus (Lacépède, 1800) & $\mathrm{N}$ & Yes & - & - & $\mathrm{X}$ & $\mathrm{X}$ & $\mathrm{X}$ & $\mathrm{X}$ \\
\hline Blenniidae & Blennius ocellaris Linnaeus, 1758 & $\mathrm{R}$ & No & - & - & - & - & - & $\mathrm{X}$ \\
\hline Congridae & Conger conger Linnaeus, 1758 & $\mathrm{R}$ & Yes & - & - & - & - & $\mathrm{X}$ & - \\
\hline Blenniidae & Parablennius gattoruqine (Linnaeus, 1758) & $\mathrm{R}$ & No & _- & _- & _- & _ & $\mathrm{X}$ & _ \\
\hline Scorpaenidae & Scorpaena notata Rafinesque, 1810 & $\mathrm{R}$ & Yes & - & - & $\mathrm{X}$ & $\mathrm{X}$ & $\mathrm{X}$ & $\mathrm{X}$ \\
\hline Scorpaenidae & Scorpaena porcus Linnaeus, 1758 & $\mathrm{R}$ & Yes & $\mathrm{X}$ & _- & $\mathrm{X}$ & - & $\mathrm{X}$ & $\mathrm{X}$ \\
\hline Scorpaenidae & Scorpaena scrofa Linnaeus, 1758 & $\mathrm{R}$ & Yes & - & - & - & - & $\mathrm{X}$ & - \\
\hline Sparidae & Diplodus annularis (Rafinesque, 1810) & $\mathrm{R}$ & Yes & _- & $\mathrm{X}$ & _- & _ & - & _ \\
\hline Sparidae & Diplodus sargus (Linnaeus, 1758) & $\mathrm{R}$ & Yes & - & - & - & - & $\mathrm{X}$ & $\mathrm{X}$ \\
\hline Sparidae & Diplodus vulgaris (Geoffroy St-Hilaire, 1817) & $\mathrm{R}$ & Yes & _ & _- & _- & _- & $\mathrm{X}$ & - \\
\hline Mullidae & Mullus surmuletus Linnaeus, 1758 & $\mathrm{R}$ & Yes & $\mathrm{X}$ & $\mathrm{X}$ & - & - & - & $\mathrm{X}$ \\
\hline Gadidae & Phycis phycis (Linnaeus, 1766) & $\mathrm{R}$ & Yes & $\mathrm{X}$ & $\mathrm{X}$ & $\mathrm{X}$ & $\mathrm{X}$ & $\mathrm{X}$ & $\mathrm{X}$ \\
\hline Serranidae & Serranus cabrilla (Linnaeus, 1758) & $\mathrm{R}$ & Yes & - & - & - & - & $\mathrm{X}$ & $\mathrm{X}$ \\
\hline Labridae & Symphodus mediterraneus (Linnaeus, 1758 ) & $\mathrm{R}$ & No & _ & _- & _- & - & $\mathrm{X}$ & - \\
\hline Triglidae & Chelidonichthys lucerna (Linnaeus, 1758) & $\mathrm{S}$ & Yes & $\mathrm{X}$ & $\mathrm{X}$ & $\mathrm{X}$ & - & $\mathrm{X}$ & $\mathrm{X}$ \\
\hline Triglidae & Chelidonichthys obscura (Linnaeus, 1764) & $\mathrm{S}$ & Yes & $\mathrm{X}$ & $\mathrm{X}$ & $\mathrm{X}$ & $\mathrm{X}$ & $\mathrm{X}$ & $\mathrm{X}$ \\
\hline Trachinidae & Echiichthys vipera (Cuvier, 1829) & $\mathrm{S}$ & No & $\mathrm{X}$ & $\mathrm{X}$ & - & - & $\mathrm{X}$ & $\mathrm{X}$ \\
\hline Triglidae & Eutrigla gurnardus (Linnaeus, 1758) & $\mathrm{S}$ & Yes & $\mathrm{X}$ & $\mathrm{X}$ & $\mathrm{X}$ & $\mathrm{X}$ & - & - \\
\hline Lophiidae & Lophius piscatorius Linnaeus, 1758 & $\mathrm{~S}$ & Yes & - & $\mathrm{X}$ & $\mathrm{X}$ & - & $\mathrm{X}$ & $\mathrm{X}$ \\
\hline Mullidae & Mullus barbatus Linnaeus, 1758 & $\mathrm{~S}$ & Yes & _ & - & $\mathrm{X}$ & $\mathrm{X}$ & - & $\mathrm{X}$ \\
\hline Sparidae & Pagellus acarne (Risso, 1826) & $\mathrm{S}$ & Yes & $\mathrm{X}$ & $\mathrm{X}$ & $\mathrm{X}$ & $\mathrm{X}$ & $\mathrm{X}$ & $\mathrm{X}$ \\
\hline Sparidae & Pagellus erythrinus (Linnaeus, 1758) & $\mathrm{S}$ & Yes & $\mathrm{X}$ & $\mathrm{X}$ & - & $\mathrm{X}$ & $\mathrm{X}$ & $\mathrm{X}$ \\
\hline Sparidae & Pagrus pagrus (Linnaeus, 1758) & $\mathrm{S}$ & Yes & - & - & - & - & $\mathrm{X}$ & - \\
\hline Soleidae & Pegusa theophilus Risso, 1810 & $\mathrm{~S}$ & Yes & $\mathrm{X}$ & $\mathrm{X}$ & $\mathrm{X}$ & $\mathrm{X}$ & - & $\mathrm{X}$ \\
\hline Scophthalmidae & Phrynorhombus regius (Bonnaterre, 1788) & $\mathrm{S}$ & No & - & - & - & - & $\mathrm{X}$ & - \\
\hline Scophthalmidae & Psetta maxima (Linnaeus, 1758) & $\mathrm{S}$ & Yes & - & $\mathrm{X}$ & - & - & - & - \\
\hline Rajidae & Raja asterias Delaroche, 1809 & $\mathrm{~S}$ & Yes & - & $\mathrm{X}$ & $\mathrm{X}$ & $\mathrm{X}$ & $\mathrm{X}$ & $\mathrm{X}$ \\
\hline Rajidae & Raja brachyura Lafont, 1873 & $\mathrm{~S}$ & Yes & - & - & - & - & $\mathrm{X}$ & - \\
\hline Rajidae & Raja clavata Linnaeus, 1758 & $\mathrm{~S}$ & Yes & - & - & $\mathrm{X}$ & - & - & - \\
\hline Scophthalmidae & Scophthalmus rhombus (Linnaeus, 1758) & $\mathrm{S}$ & Yes & $\mathrm{X}$ & $\mathrm{X}$ & $\mathrm{X}$ & $\mathrm{X}$ & $\mathrm{X}$ & $\mathrm{X}$ \\
\hline Soleidae & Solea solea (Linnaeus, 1758) & $\mathrm{S}$ & Yes & $\mathrm{X}$ & $\mathrm{X}$ & $\mathrm{X}$ & $\mathrm{X}$ & $\mathrm{X}$ & $\mathrm{X}$ \\
\hline Torpedinidae & Torpedo marmorata Risso, 1810 & $\mathrm{~S}$ & No & $\mathrm{X}$ & $\mathrm{X}$ & $\mathrm{X}$ & $\mathrm{X}$ & $\mathrm{X}$ & $\mathrm{X}$ \\
\hline Uranoscopidae & Uranoscopus scaber Linnaeus, 1758 & $\mathrm{~S}$ & Yes & $\mathrm{X}$ & $\mathrm{X}$ & $\mathrm{X}$ & - & $\mathrm{X}$ & $\mathrm{X}$ \\
\hline Sparidae & Sarpa salpa (Linnaeus, 1758) & $\mathrm{V}$ & Yes & - & $\mathrm{X}$ & - & - & - & - \\
\hline \multicolumn{10}{|c|}{ (B) Invertebrate species } \\
\hline Loliginidae & Loligo vulgaris Lamarck, 1798 & $\mathrm{~N}$ & Yes & - & - & - & - & - & $\mathrm{X}$ \\
\hline Sepiidae & Sepia officinalis Linnaeus, 1758 & $\mathrm{~N}$ & Yes & $\mathrm{X}$ & $\mathrm{X}$ & - & $\mathrm{X}$ & $\mathrm{X}$ & $\mathrm{X}$ \\
\hline Dromidae & Dromia sp. & $\mathrm{R}$ & No & - & - & - & - & $\mathrm{X}$ & $\mathrm{X}$ \\
\hline Galatheidae & Galathea strigosa (Linnaeus, 1758) & $\mathrm{R}$ & No & - & - & - & - & $\mathrm{X}$ & - \\
\hline Nephropidae & Homarus gammarus (Linnaeus, 1758) & $\mathrm{R}$ & Yes & $\mathrm{X}$ & - & - & - & $\mathrm{X}$ & $\mathrm{X}$ \\
\hline Portunidae & Necora puber Linnaeus, 1758 & $\mathrm{R}$ & Yes & - & - & - & - & $\mathrm{X}$ & - \\
\hline Octopodidae & Octopus vulgaris Cuvier, 1797 & $\mathrm{R}$ & Yes & $\mathrm{X}$ & $\mathrm{X}$ & $\mathrm{X}$ & $\mathrm{X}$ & $\mathrm{X}$ & $\mathrm{X}$ \\
\hline Palinuridae & Palinurus elephas (Fabricius, 1787) & $\mathrm{R}$ & Yes & - & $\mathrm{X}$ & - & - & $\mathrm{X}$ & $\mathrm{X}$ \\
\hline Scyllaridae & Scyllarus arctus (Linnaeus, 1758) & $\mathrm{R}$ & No & - & - & - & - & $\mathrm{X}$ & $\mathrm{X}$ \\
\hline Echinidae & Paracentrotus lividus (Lamarck, 1816) & RV & Yes & - & - & - & - & $\mathrm{X}$ & - \\
\hline Echinidae & Sphaerechinus granularis (Lamarck, 1816) & RV & Yes & - & - & - & - & $\mathrm{X}$ & - \\
\hline Cardiidae & Acanthocardia aculeata (Linnaeus, 1758) & $\mathrm{S}$ & No & - & - & $\mathrm{X}$ & - & - & $\mathrm{X}$ \\
\hline Muricidae & Bolinus brandaris (Linnaeus, 1758) & $\mathrm{S}$ & Yes & $\mathrm{X}$ & $\mathrm{X}$ & $\mathrm{X}$ & $\mathrm{X}$ & $\mathrm{X}$ & $\mathrm{X}$ \\
\hline Veneridae & Callista chione (Linnaeus, 1758) & $\mathrm{S}$ & No & - & - & $\mathrm{X}$ & - & - & - \\
\hline Cardiidae & Cardiidae sp. & $\mathrm{S}$ & No & _ & $\mathrm{X}$ & $\mathrm{X}$ & $\mathrm{X}$ & $\mathrm{X}$ & $\mathrm{X}$ \\
\hline Naticidae & Cassidaria echinophora (Linnaeus, 1758) & $\mathrm{S}$ & Yes & - & $\mathrm{X}$ & - & - & $\mathrm{X}$ & $\mathrm{X}$ \\
\hline Caradiidae & Cerastoderma edule (Linnaeus, 1758) & $\mathrm{S}$ & Yes & $\mathrm{X}$ & $\mathrm{X}$ & - & - & - & $\mathrm{X}$ \\
\hline Muricidae & Hexaplex trunculus (Linnaeus, 1758) & $\mathrm{S}$ & Yes & $\mathrm{X}$ & $\mathrm{X}$ & - & - & - & - \\
\hline Naticidae & Natica millpuncata (Lamarck, 1822) & $\mathrm{S}$ & No & - & - & _- & - & _- & $\mathrm{X}$ \\
\hline Pectinidae & Pectinidae sp. & $\mathrm{S}$ & Yes & - & - & - & - & $\mathrm{X}$ & - \\
\hline Squillidae & Squilla mantis (Linnaeus, 1758) & $\mathrm{S}$ & No & - & - & $\mathrm{X}$ & $\mathrm{X}$ & $\mathrm{X}$ & $\mathrm{X}$ \\
\hline Turbinidae & Turbinidae sp. & $\mathrm{S}$ & No & - & - & - & - & $\mathrm{X}$ & - \\
\hline
\end{tabular}




\section{Spatial differences in community structure}

At Agde and Valras, the nMDS plot combined with a hierarchical cluster analysis indicated that the composition of communities was similar between NRs and ARs and among the stations (40\% similarity; Fig. 3). Rock-preferring and sand-preferring species were caught in similar proportions. There was no
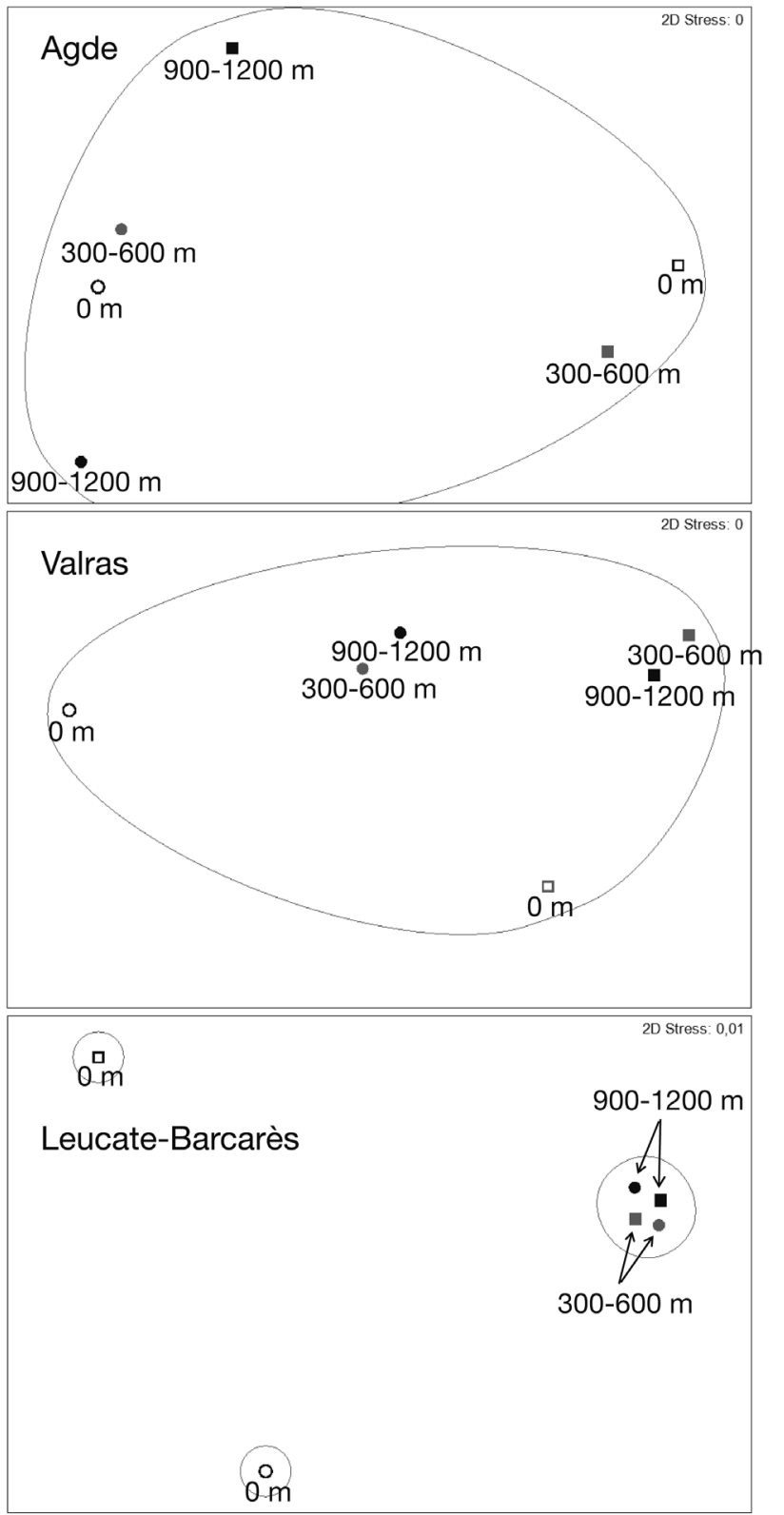

Fig. 3. Nonmetric multidimensional scaling ordination combined with hierarchical clustering of fish and invertebrate species abundance observed at each site (artificial reef: $\bullet$; natural rocky area: $\mathbf{m})$ and station (numbers correspond to distance of station from site in $\mathrm{m}$ ) for each locality (Agde, Valras and Leucate-Barcarès). Clusters were grouped at a similarity level of $40 \%$ gradient with distance at Agde for rock-preferring or sand-preferring species. At Valras, distance gradients were found only for sand-preferring species, for total species and for CPUE (Table 3). The results differed at Leucate-Barcarès for rock- and sandpreferring species and at Valras for rock-preferring species. The assemblage differed among NR-Near, AR-Near and the other stations only at LeucateBarcarès. Significant differences were detected by the ANOSIM among the sites and stations but not by the nMDS plot, which is simply a graphical representation of an exploratory method.

Leucate-Barcarès showed differences in community composition among the sites and stations (ANOSIM: $\mathrm{R}=0.36, \mathrm{p}<0.01$; $\mathrm{R}=0.61, \mathrm{p}<0.01$, respectively), with a significant difference between Near and Medium and between Near and Far (Near-Medium: $\mathrm{R}=0.87, \mathrm{p}<0.01$; Near-Far: $\mathrm{R}=0.74, \mathrm{p}<0.01)$. A SIMPER analysis indicated that the species Bolinus brandaris, Raja asterias, Solea solea, Trisopterus luscus capelanus, Chelidonichthys obscurus, Phycis phycis and Scorpaena notata were primary contributors to the observed dissimilarity among sites and stations $(52.28 \%)$. The reason for the dissimilarity between NR and AR $(77.66 \%$, Table 4) was that B. brandaris, S. solea, T. luscus capelanus and C. obscurus were more abundant at AR than at NR. Other species were more abundant at NR than at AR. The reason for the dissimilarity between Near and

Table 3. Summary of total species and catch per unit effort (CPUE: ind. $300 \mathrm{~m}^{-1}$ night $^{-1}$ ) for fish per substratum choice (rock or sand) according to the locality and the site and station. NR: natural rocky area; AR: artificial reef

\begin{tabular}{|c|c|c|c|c|c|}
\hline \multirow{2}{*}{ Locality } & \multirow{2}{*}{ Site-Station } & \multicolumn{2}{|c|}{ Total species } & \multicolumn{2}{|c|}{ Total CPUE } \\
\hline & & Rock & Sand & Rock & Sand \\
\hline \multirow[t]{6}{*}{ Agde } & NR-Near & 2 & 7 & 0.15 & 1.30 \\
\hline & NR-Medium & 1 & 8 & 0.05 & 1.60 \\
\hline & NR-Far & 2 & 9 & 0.25 & 5.30 \\
\hline & AR-Near & 0 & 9 & 0.00 & 9.30 \\
\hline & AR-Medium & 1 & 9 & 0.20 & 9.00 \\
\hline & AR-Far & 3 & 13 & 0.25 & 9.30 \\
\hline \multirow[t]{6}{*}{ Valras } & NR-Near & 3 & 11 & 1.90 & 4.60 \\
\hline & NR-Medium & 1 & 4 & 0.10 & 6.80 \\
\hline & NR-Far & 0 & 7 & 0.00 & 5.00 \\
\hline & AR-Near & 2 & 9 & 0.30 & 4.60 \\
\hline & AR-Medium & 0 & 6 & 0.00 & 3.80 \\
\hline & AR-Far & 0 & 7 & 0.00 & 4.70 \\
\hline \multirow[t]{6}{*}{ Leucate-Barcarès } & NR-Near & 10 & 6 & 8.30 & 0.50 \\
\hline & NR-Medium & 2 & 11 & 0.30 & 4.40 \\
\hline & NR-Far & 0 & 8 & 0.00 & 5.10 \\
\hline & AR-Near & 6 & 9 & 2.30 & 4.80 \\
\hline & AR-Medium & 1 & 10 & 0.10 & 6.30 \\
\hline & AR-Far & 0 & 9 & 0.00 & 3.40 \\
\hline
\end{tabular}


Table 4. Results of SIMPER for species producing a difference between assemblages of $50 \%$ for Leucate-Barcarès as a function of the factors 'Sites' and 'Station'. NR: natural rocky area; AR: artificial reef

\begin{tabular}{|c|c|c|c|c|}
\hline & $\begin{array}{c}\text { Mean } \\
\text { lissimilar } \\
\qquad \%)\end{array}$ & Species & $\begin{array}{c}\text { Dissimi- } \\
\text { larity } \\
(\%)\end{array}$ & $\begin{array}{c}\text { Accumulated } \\
\text { dissimilarity } \\
(\%)\end{array}$ \\
\hline \multicolumn{5}{|l|}{ Site } \\
\hline \multirow[t]{7}{*}{ NR/AR } & \multirow[t]{7}{*}{77.66} & Bolinus brandaris & 14.02 & 14.02 \\
\hline & & Raja asterias & 10.96 & 24.98 \\
\hline & & Solea solea & 9.58 & 34.57 \\
\hline & & Trisopterus luscus capelanus & 4.60 & 39.17 \\
\hline & & Phycis phycis & 4.54 & 43.71 \\
\hline & & Chelidonichthys obscura & 4.41 & 48.12 \\
\hline & & Scorpaena notata & 4.16 & 52.28 \\
\hline \multicolumn{5}{|l|}{ Station } \\
\hline \multirow[t]{6}{*}{ Near/Medium } & \multirow[t]{6}{*}{94.31} & Bolinus brandaris & 15.93 & 15.93 \\
\hline & & Scorpaena notata & 9.58 & 25.50 \\
\hline & & Solea solea & 8.38 & 33.88 \\
\hline & & Phycis phycis & 7.31 & 41.20 \\
\hline & & Raja asterias & 6.38 & 47.58 \\
\hline & & Trisopterus luscus capelanus & 5.79 & 53.37 \\
\hline \multirow[t]{7}{*}{ Near/Far } & \multirow[t]{7}{*}{94.82} & Scorpaena notata & 10.97 & 10.97 \\
\hline & & Phycis phycis & 8.41 & 19.38 \\
\hline & & Trisopterus luscus capelanus & 7.28 & 26.66 \\
\hline & & Solea solea & 7.11 & 33.76 \\
\hline & & Raja asterias & 6.55 & 40.31 \\
\hline & & Pagellus acarne & 5.45 & 45.76 \\
\hline & & Bolinus brandaris & 4.92 & 50.68 \\
\hline
\end{tabular}

Medium was that $S$. notata, P. phycis and T. luscus capelanus dominated at Near stations. These species and Pagelus acarne were more abundant at Near than at Far stations. Others species were more abun- dant at Medium or Far than at Near stations. Medium and Far stations were characterized by species preferring sandy substratum habitats (Tables $3 \& 4$ ).

The MCA resulted in principal axes that were characterized by the category variables (test values are given in brackets). The results were only interpreted on the 2 first factorial axes, which represented the majority of the information in the data set. Fig. 4 shows that the first factorial axis contrasts the categories R (13.11), NR-Near (10.83) and Leucate-Barcarès (9.35), with positive coordinates, with the categories AR-Far (-2.51), ARMedium (-4.27), Valras (-4.62), Agde (-5.52), NR-Far (-6.40) and $\mathrm{V}(-11.41)$, with negative coordinates. This result suggests that the Leucate-Barcarès locality differs from Valras and Agde in terms of total number of species, with fewer total species at Valras and Agde. The total richness found at Leucate-Barcarès was similar to that found at the NR-Near stations, with a majority of species on rocky substratum. In contrast, the total richness found at the Valras and Agde

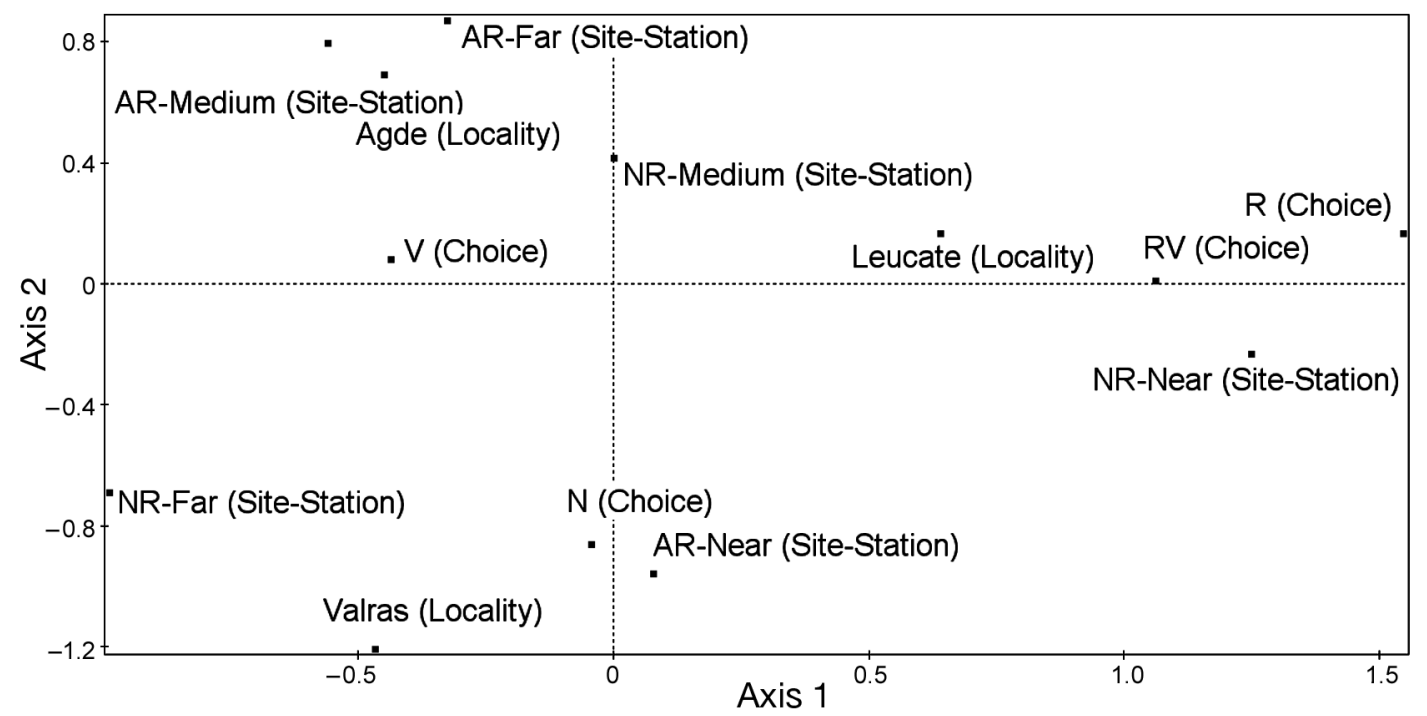

Fig. 4. Projection of variable categories on the first 2 factorial axes obtained from multiple correspondence factorial analysis of the total number of species caught for the following 3 categorical variables: Locality, with 3 categories (Agde, Valras and Leucate-Barcarès), substratum choice (Choice), with 5 categories (no choice [N], soft substrate such as mud/sand [S], rocky [R], vegetated substrate such as seaweed $[\mathrm{V}]$, rocky and vegetated substrate [RV]) and Site-Station, with 6 categories (AR-Near, AR-Medium, AR-Far, NR-Near, NR-Medium and NR-Far). NR: Natural rocky area; AR: artificial reef 
localities was similar to that found at the NR-Far, AR-Medium and AR-Far sites and stations, with a majority of species on vegetated substrates (e.g. seaweed). The second factorial axis contrasts the localities at Agde with positive coordinates with those at Valras with negative coordinates. Agde (8.47) was characterized to a certain extent by species on vegetated substrates (2.05) and is similar to the AR-Far (6.72), AR-Medium (6.07) and NR-Medium (2.85) sites and stations. The Valras (-12) locality was characterized by species with no substratum choice (-4.98) and most closely resembled AR-Near (8.48). Valras also resembled NR-Far (-4.50) and NR-Near $(-2.03)$.

\section{Species richness}

The analyses showed that fish species richness was significantly higher in the vicinity of ARs $(3.0 \pm 1.7)$ than NRs $(1.8 \pm 1.4)$ at Agde (Table 5). For the 2 other localities, the fish species richness of the ARs and NRs was similar (Table 5). However, the analyses showed significant differences among the stations (Table 5) due to higher species richness at the Near than at the Medium or Far stations (Fig. 5).

The species richness of invertebrates was only significantly different at Leucate-Barcarès (Table 5). It was higher at AR-Medium than at AR-Near, and NRNear had higher richness than NR-Far (Fig. 5). Fur-

Table 5. Factors influencing fish and Bolinus brandaris (invertebrate) populations at the studied localities (Agde, Valras and Leucate-Barcarès) and F-values of the tests used. Significant results are in bold. See Fig. 5 for post-hoc results

\begin{tabular}{|c|c|c|c|c|}
\hline \multirow[t]{2}{*}{ Factor } & \multicolumn{2}{|c|}{ Fish } & \multicolumn{2}{|c|}{ Invertebrate ( $B$. brandaris) } \\
\hline & $F$ & $\mathrm{p}$ & $F$ & $\mathrm{p}$ \\
\hline \multicolumn{5}{|l|}{ Species richness } \\
\hline Agde & \multicolumn{2}{|c|}{ 2-way ANOVA Permutations } & \multicolumn{2}{|c|}{ 2-way ANOVA Permutations } \\
\hline Site & 9.6787 & 0.0029 & 0.7534 & 0.3567 \\
\hline Station & 1.6190 & 0.2075 & 0.8162 & 0.4268 \\
\hline Site $\times$ Station & 0.1767 & 0.8385 & 2.3232 & 0.1092 \\
\hline Valras & \multicolumn{2}{|c|}{ 2-way ANOVA Permutations } & \multicolumn{2}{|c|}{ 2-way ANOVA Permutations } \\
\hline Site & 0.0579 & 0.8107 & 1.1900 & 0.2619 \\
\hline Station & 9.0434 & 0.0004 & 2.0826 & 0.1271 \\
\hline Site $\times$ Station & 1.1014 & 0.3406 & 0.0992 & 0.9008 \\
\hline Leucate-Barcarès & \multicolumn{2}{|c|}{ 2-way ANOVA Permutations } & \multicolumn{2}{|c|}{ 2-way ANOVA Permutations } \\
\hline Site & 0.4848 & 0.4700 & 4.6272 & 0.0383 \\
\hline Station & 7.7954 & 0.0011 & 2.5102 & 0.0889 \\
\hline Site $\times$ Station & 0.0530 & 0.5784 & 17.0167 & 0.0001 \\
\hline \multicolumn{5}{|l|}{ CPUE of individuals } \\
\hline Agde & \multicolumn{2}{|c|}{ 2-way ANOVA } & \multicolumn{2}{|c|}{ 2-way ANOVA Permutations } \\
\hline Site & 15.0803 & 0.0002 & 4.16775 & 0.0409 \\
\hline Station & 0.9718 & 0.3849 & 0.9722 & 0.4045 \\
\hline Site $\times$ Station & 3.0402 & 0.0561 & 0.9314 & 0.9420 \\
\hline Valras & \multicolumn{2}{|c|}{ Scheirer-Ray-Hare } & \multicolumn{2}{|c|}{ 2-way ANOVA Permutations } \\
\hline Site & 2.6961 & 0.1071 & 5.8079 & 0.0222 \\
\hline Station & 3.2793 & 0.0462 & 1.5169 & 0.2320 \\
\hline Site $\times$ Station & 0.3015 & 0.7412 & 0.0861 & 0.9179 \\
\hline Leucate-Barcarès & \multicolumn{2}{|c|}{ 2-way ANOVA } & \multicolumn{2}{|c|}{ Scheirer-Ray-Hare } \\
\hline Site & 1.5162 & 0.2235 & 0.1246 & 0.7254 \\
\hline Station & 11.6918 & $<0.0001$ & 45.0298 & $<0.0001$ \\
\hline Site $\times$ Station & 1.8316 & 0.170 & 17.1182 & $<0.0001$ \\
\hline \multicolumn{5}{|l|}{ CPUE of biomass } \\
\hline Agde & \multicolumn{2}{|c|}{ Scheirer-Ray-Hare } & \multicolumn{2}{|c|}{ 2-way ANOVA Permutations } \\
\hline Site & 12.2297 & 0.0009 & 3.9732 & 0.0410 \\
\hline Station & 1.0331 & 0.3628 & 0.9065 & 0.4110 \\
\hline Site $\times$ Station & 3.3310 & 0.0432 & 0.7630 & 0.7690 \\
\hline Valras & 2-way A & utations & & \\
\hline Site & 19.4084 & 0.0001 & 4.2515 & 0.0464 \\
\hline Station & 4.9661 & 0.0096 & 1.0456 & 0.3619 \\
\hline Site $\times$ Station & 2.1392 & 0.1251 & 0.0869 & 0.9169 \\
\hline Leucate-Barcarès & 2-way A & utations & Sch & are \\
\hline Site & 2.8237 & 0.788 & 0.0350 & 0.8524 \\
\hline Station & 0.7195 & 0.5602 & 47.0630 & $<0.0001$ \\
\hline Site $\times$ Station & 1.0525 & 0.3904 & 19.0120 & $<0.0001$ \\
\hline
\end{tabular}


A

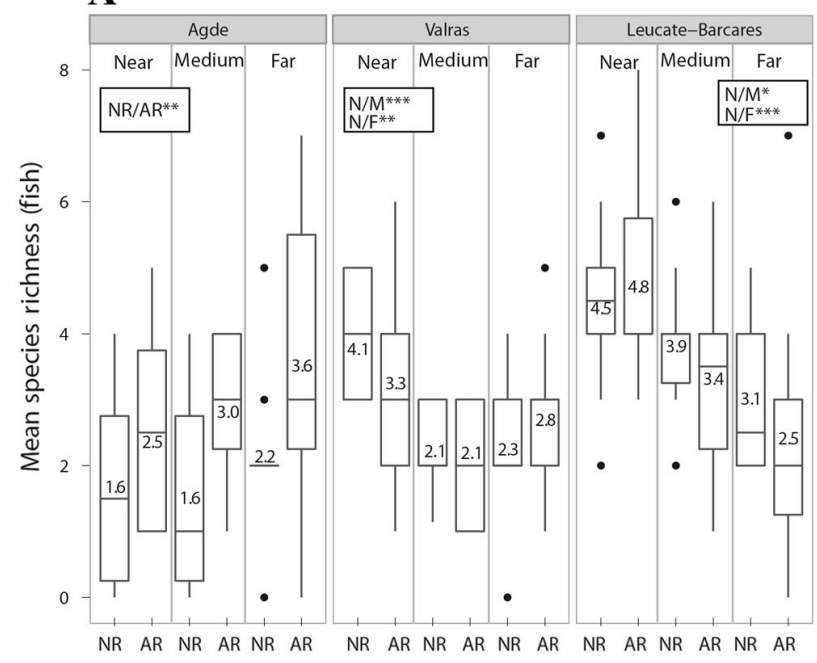

C

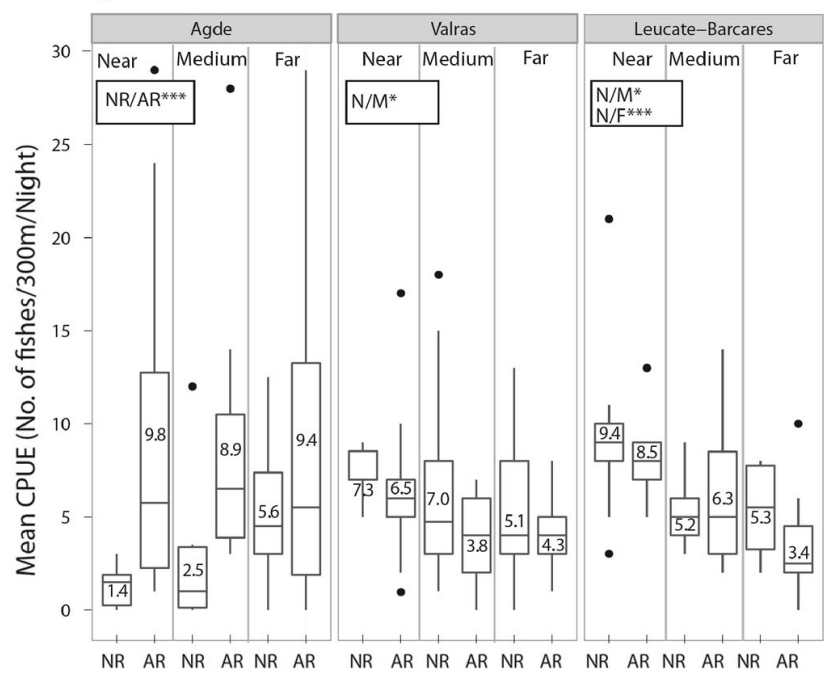

E

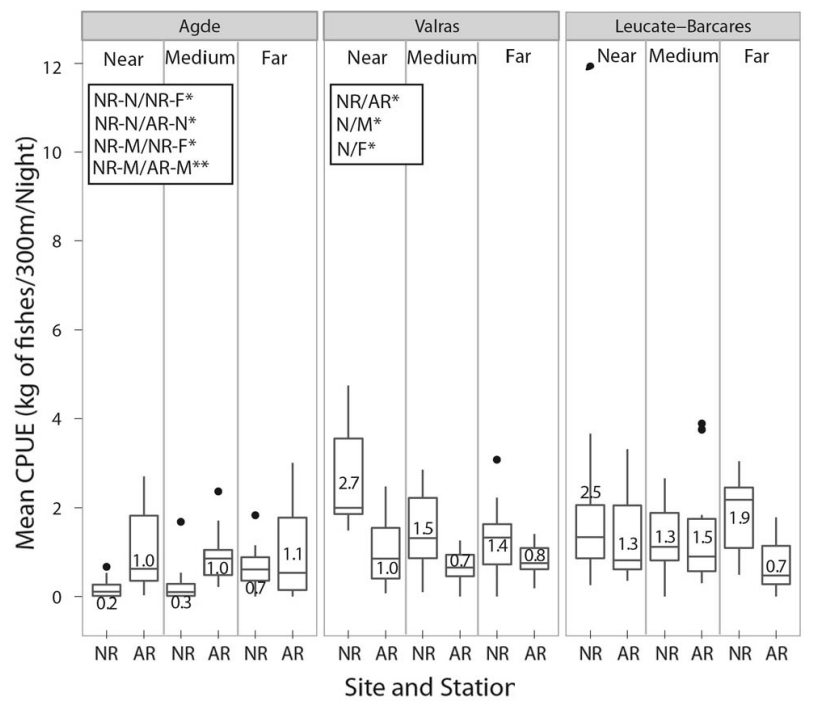

B

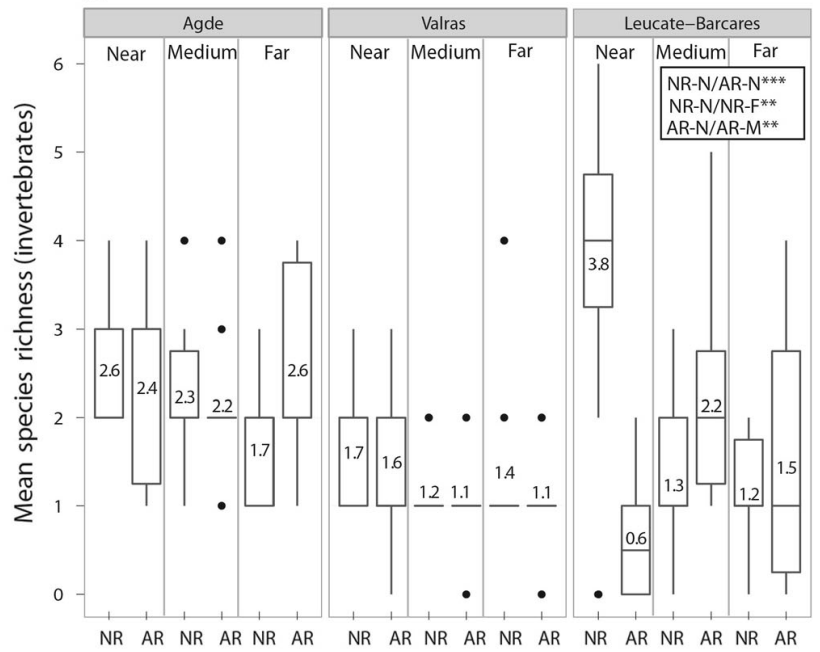

D

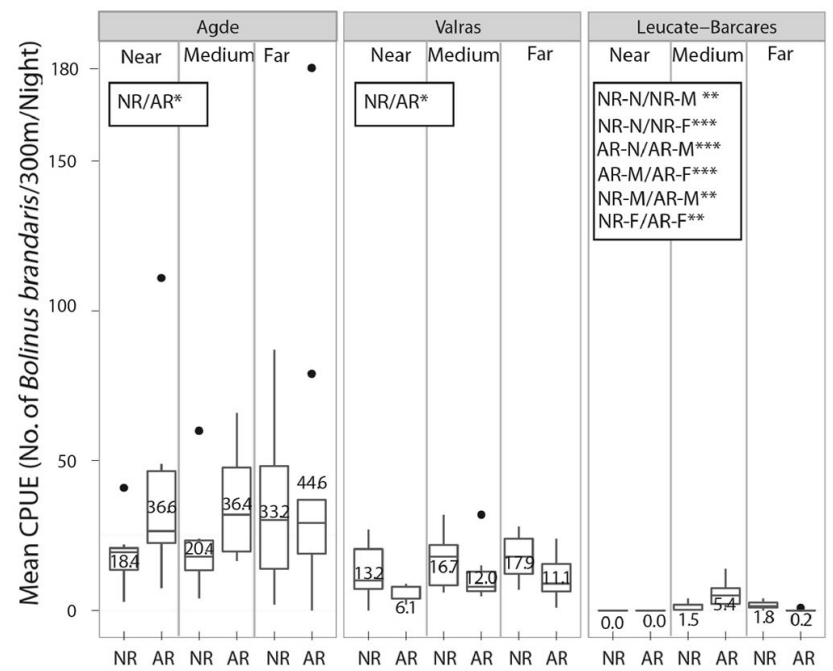

F

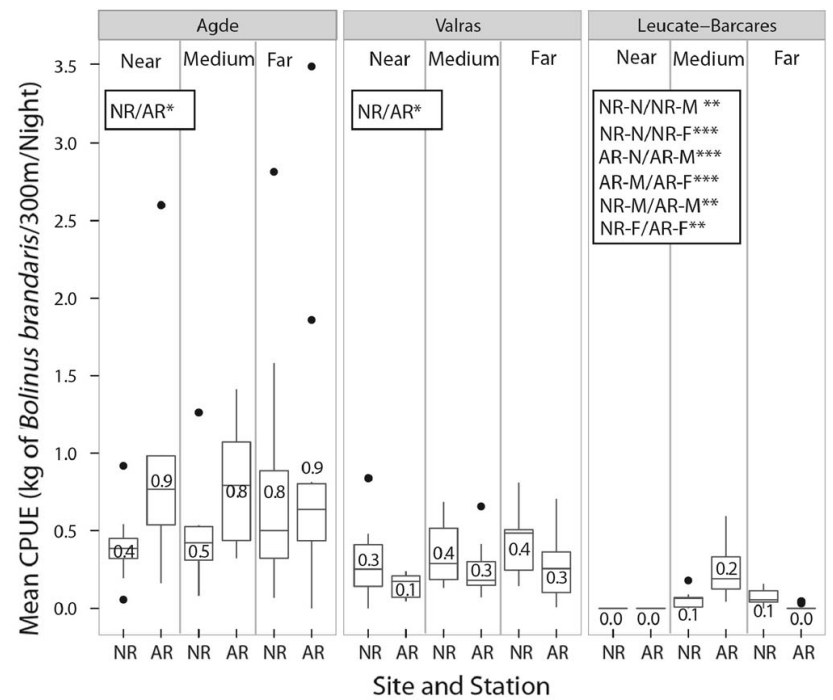

Fig. 5. Mean species richness of (A) fish and (B) invertebrates, mean CPUE of individuals for (C) fish and (D) Bolinus brandaris and mean CPUE of biomass for (E) fish and (F) B. brandaris per locality (Agde, Valras and Leucate-Barcarès), site (artificial reef: $A_{i}$ natural rocky area: NR) and station (Near: $N_{i}$ Medium: $M_{i}$ Far: F). The values indicate the mean, the horizontal bars the median, and the vertical lines the minimum and maximum values, excluding outliers, which are indicated by black dots. ${ }^{*} \mathrm{p}<0.05,{ }^{* *} \mathrm{p}<0.001,{ }^{* * *} \mathrm{p}<0.001$ 
thermore, invertebrate species richness was higher at NR-Near than at AR-Near (Fig. 5).

\section{CPUE of individuals}

The fish CPUE of individuals (number of fish $300 \mathrm{~m}^{-1}$ night $^{-1}$ ) was significantly higher in the vicinity of the AR $(9.4 \pm 9.1)$ than in the NR site $(3.1 \pm 3.5)$ at Agde (Table 5, Fig. 5). At Valras and LeucateBarcarès, the values differed significantly among stations (Table 5) due to a higher CPUE of individuals at the Near than at the Medium station for Valras and a higher CPUE of individuals at the Near station than at the Medium and the Far stations for LeucateBarcarès (Fig. 5).

The CPUE of individuals for Bolinus brandaris (number of $B$. brandaris $300 \mathrm{~m}^{-1}$ night $^{-1}$ ) was significantly higher in the vicinity of the AR than the NR at Agde, whereas the opposite was true at Valras (Fig. 5, Table 5). At Leucate-Barcarès, there was an interaction between Site and Station (Table 5). The $B$. brandaris CPUE of individuals was higher at ARMedium than at AR-Near or AR-Far (Fig. 5). For the $\mathrm{NR}$, it increased with distance.

\section{CPUE of biomass}

The analysis revealed different trends for fish CPUE of biomass ( $\mathrm{kg}$ of fish $300 \mathrm{~m}^{-1}$ night $^{-1}$ ) by locality (Table 5). At Agde, values were similar between the stations for the AR $(1.02 \pm 0.90)$, whereas they were higher at the Far station than at the Near and Medium stations for NR (Fig. 5). Furthermore, at the Near and Medium stations, fish CPUE of biomass was higher at AR than at NR (Fig. 5). At Valras, the fish CPUE of biomass was always higher in the vicinity of the NR $(1.85 \pm 1.17)$ than at the AR $(0.84 \pm 0.55)$ and higher at Near $(1.86 \pm$ 1.33) than at Medium (1.09 \pm 0.81$)$ or Far $(1.08 \pm 10.73)$ (Fig. 5) stations. The fish CPUE of biomass at Leucate-Barcarès did not differ among sites or stations.

The $B$. brandaris CPUE biomass (kg $300 \mathrm{~m}^{-1}$ night $^{-1}$ ) followed the same trend as the CPUE of individuals for all 3 localities (Table 5, Fig. 5).

\section{Size structure}

Medium-size fish were higher in CPUE of individuals (number of fish $300 \mathrm{~m}^{-1}$ night $^{-1}$ ) than Small and Large fish at the Agde AR $(8.48 \pm 8.97$ vs. $0.35 \pm 0.78$ and $0.35 \pm 0.58$, respectively; Table 6 ; post-hoc: $\mathrm{p}<0.0001$ for both). The same trend was observed at the Valras AR $(4.25 \pm 3.26$ vs. $0.53 \pm 0.62$ and $0.70 \pm 1.46$, respectively; Table 6; post-hoc: $\mathrm{p}<0.0001$ for both). Medium fish also dominated at the NR (Agde: $2.96 \pm$ 3.50; Table 6 ; post-hoc: $\mathrm{p}<0.0001$ for both, and Valras: $5.11 \pm 4.28$; Table 6 ; post-hoc: $\mathrm{p}<0.0001$ for both). However, Large fish were present in the same proportion as Medium fish, and Small fish dominated (Large: $2.87 \pm 1.90$; Medium: $4.18 \pm 2.86$ ) at NR-Near Valras compared with AR-Near. A similar pattern was observed at Leucate-Barcarès at both the AR and NR; for the other stations, the Medium fish dominated.

For $B$. brandaris, no differences in individual weight among the sites or the stations of a site were found at any of the 3 localities or between any stations at the same locality. At Agde and Valras, the average individual weight was $22 \mathrm{~g}$, whereas it was $40 \mathrm{~g}$ at Leucate-Barcarès.

\section{Soleidae}

In general, the CPUE (number of fish $300 \mathrm{~m}^{-1}$ night $^{-1}$ ) of Soleidae was similar among stations (Table 7) except at Leucate-Barcarès, where it was higher at Medium and Far than at Near for both the AR and NR (Fig. 6). Furthermore, at Agde, the CPUE of individuals was higher in the vicinity of the AR $(7.40 \pm 8.21)$ than in the vicinity of the NR $(1.88 \pm 3.20)$. At Leucate-Barcarès, the CPUE of individuals was only higher at the AR compared with the NR for Medium (Fig. 6). The CPUE biomass of Soleidae was similar among stations both at the AR and NR at Agde and Valras but not at Leucate-Barcarès, where the CPUE biomass was higher at Medium and Far than at Near (Fig. 6). However, at Agde, the CPUE of biomass was

Table 6. Results of the Scheirer-Ray-Hare test used to identify differences in fish size structure by site (artificial reef and natural reef) and locality (Agde, Valras and Leucate-Barcarès) based on the F-value of the test. Significant results are in bold

\begin{tabular}{|llrrrr|}
\hline \multirow{2}{*}{ CPUE of ind. } & Factor & \multicolumn{2}{c}{ Artificial reef } & \multicolumn{2}{c|}{ Natural reef } \\
& & $F$ & $\mathrm{p}$ & $F$ & $\mathrm{p}$ \\
\hline \multirow{2}{*}{ Agde } & Station & 0.1006 & 0.9044 & 4.3792 & $\mathbf{0 . 0 1 5 6}$ \\
& Size & 45.0153 & $<\mathbf{0 . 0 0 0 1}$ & 43.0646 & $<\mathbf{0 . 0 0 0 1}$ \\
& Station $\times$ Size & 0.6859 & 0.6038 & 0.7570 & 0.5563 \\
Valras & Station & 1.3313 & 0.2705 & 5.3788 & $\mathbf{0 . 0 0 6 6}$ \\
& Size & 56.6077 & $<\mathbf{0 . 0 0 0 1}$ & 51.5275 & $<\mathbf{0 . 0 0 0 1}$ \\
& Station $\times$ Size & 1.0756 & 0.3749 & 4.9502 & $\mathbf{0 . 0 0 1 3}$ \\
Leucate-Barcarès & Station & 49.6276 & $<0.0001$ & 11.2752 & $<\mathbf{0 . 0 0 0 1}$ \\
& Size & 3.7785 & $\mathbf{0 . 0 2 6 9}$ & 69.1212 & $<\mathbf{0 . 0 0 0 1}$ \\
& Station $\times$ Size & 4.2685 & $\mathbf{0 . 0 0 3 4}$ & 9.9033 & $<\mathbf{0 . 0 0 0 1}$ \\
& & & & & \\
\hline
\end{tabular}


Table 7. Factors influencing Soleidae populations at the studied localities (Agde, Valras and Leucate-Barcarès) and the F-value of the test. Significant results are in bold. See Fig. 6 for post-hoc results

\begin{tabular}{|c|c|c|c|}
\hline & Factor & F & $\mathrm{p}$ \\
\hline \multicolumn{4}{|c|}{ CPUE of individuals } \\
\hline \multirow[t]{4}{*}{ Agde } & & \multicolumn{2}{|c|}{ Scheirer-Ray-Hare } \\
\hline & Site & 14.2504 & 0.0003 \\
\hline & Station & 1.2522 & 0.2940 \\
\hline & Site $\times$ Station & 2.9215 & 0.062 \\
\hline \multirow[t]{4}{*}{ Valras } & & \multicolumn{2}{|c|}{ 2-way ANOVA Permutations } \\
\hline & Site & 3.2709 & 0.54 \\
\hline & Station & 2.1609 & 0.1222 \\
\hline & Site $\times$ Station & 0.9843 & 0.3947 \\
\hline \multicolumn{2}{|c|}{ Leucate-Barcarès } & \multicolumn{2}{|c|}{ Scheirer-Ray-Hare } \\
\hline & Site & 2.0944 & 0.1536 \\
\hline & Station & 14.3762 & $<0.0001$ \\
\hline & Site $\times$ Station & 3.8908 & 0.0263 \\
\hline \multicolumn{4}{|c|}{ CPUE of biomass } \\
\hline \multirow[t]{4}{*}{ Agde } & & \multicolumn{2}{|c|}{ Scheirer-Ray-Hare } \\
\hline & Site & 8.4151 & 0.0053 \\
\hline & Station & 1.8544 & 0.1663 \\
\hline & Site $\times$ Station & 2.8450 & 0.0669 \\
\hline \multirow[t]{4}{*}{ Valras } & & \multicolumn{2}{|c|}{ Scheirer-Ray-Hare } \\
\hline & Site & 7.3925 & 0.0090 \\
\hline & Station & 1.7283 & 0.1884 \\
\hline & Site $\times$ Station & 0.5640 & 0.5726 \\
\hline \multicolumn{2}{|c|}{ Leucate-Barcarès } & \multicolumn{2}{|c|}{ Scheirer-Ray-Hare } \\
\hline & Site & 1.0899 & 0.3011 \\
\hline & Station & 14.3642 & $<0.0001$ \\
\hline & Site $\times$ Station & 2.0003 & 0.1452 \\
\hline
\end{tabular}

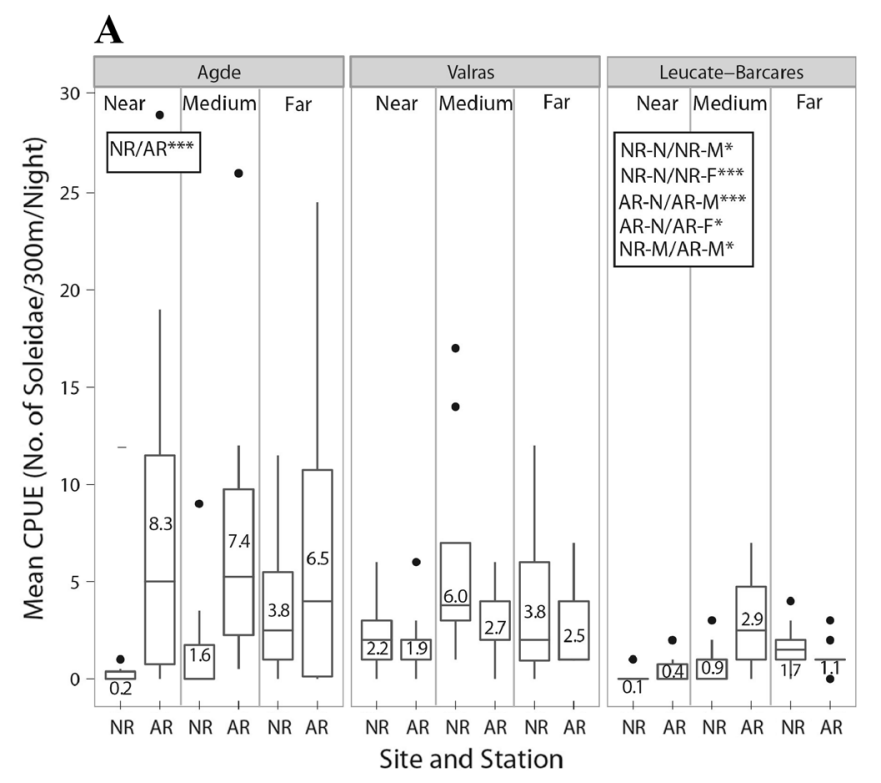

higher in the vicinity of the $\operatorname{AR}(0.67 \pm 0.73)$ than in the vicinity of the NR $(0.21 \pm 0.32)$ (Table 7$)$. The opposite pattern was found at Valras (AR: $0.30 \pm 0.24$; NR: $0.67 \pm 0.57)$.

\section{DISCUSSION}

The principal finding of this study was that the AR assemblages were similar to the NR assemblages. Furthermore, for fish, the fishing yield (in numbers) decreased with distance from the ARs, except at Agde, where it was stable. For Bolinus brandaris and the Soleidae species, all associated with soft bottoms, the fishing yield (in numbers and in weight) was not affected by increased distance from ARs, except at Leucate-Barcarès. This research also showed that fishing yield (in numbers) was similar at both ARs and NRs except for at Agde, which had a greater fishing yield at the AR than at the NR. For B. brandaris and Soleidae, it was not possible to draw a conclusion from the comparison between the AR and NR because the pattern differed for each locality.

\section{Influence of distance from the ARs}

In this study, only the Near-AR assemblage at Leucate-Barcarès was dominated by rocky-bottom species. Bombace et al. (1994) and Santos \& Mon-

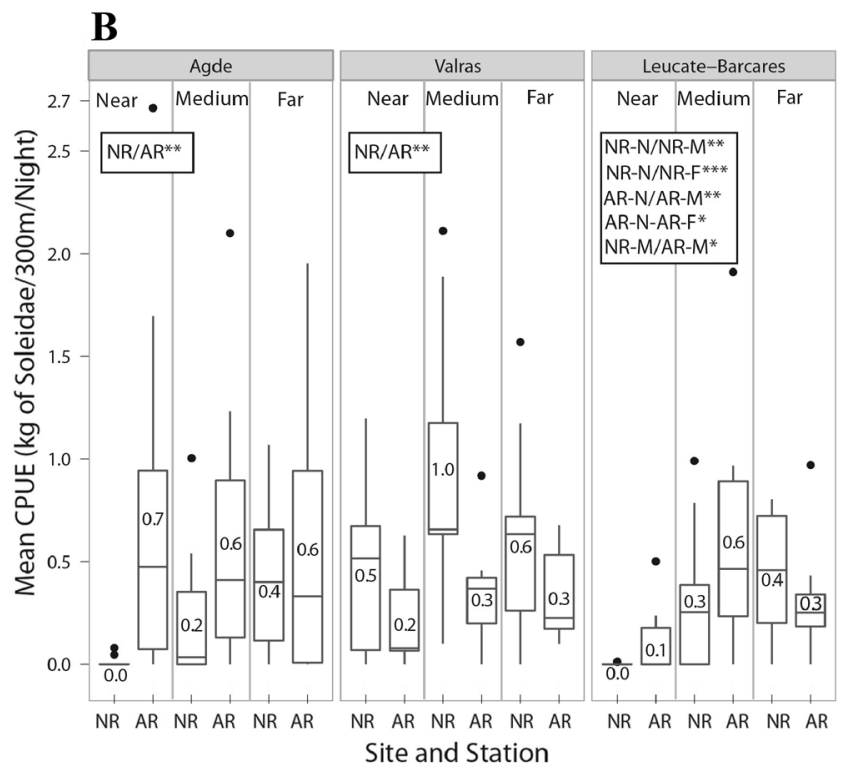

Fig. 6. Mean CPUE of (A) individuals and mean (B) CPUE of biomass for Soleidae by locality (Agde, Valras and Leucate-Barcarès), site (artificial reef: AR; natural rocky area: NR) and station (Near: N; Medium: $\mathrm{M}_{i}$ Far: F). The values indicate the mean, the horizontal bars indicate the median, and the vertical lines indicate the minimum and maximum values, excluding outliers, which are indicated by black dots. ${ }^{*} \mathrm{p}<0.05,{ }^{* *} \mathrm{p}<0.001,{ }^{* * *} \mathrm{p}<0.001$ 
teiro (2007) showed that deployment of ARs on sandy-mud bottoms modified the existing communities by increasing the rock-preferring species. In these studies, the authors stated that the AR most likely offered the rock-preferring species a habitat that provided refuges or food in their neighborhood. At the Medium and Far stations of the ARs in our study, the substrate was sandy, so very few rockpreferring species were encountered. However, at Agde and Valras, the results contradicted those of previous studies. The AR assemblages at the Near station were dominated by sand-preferring species or species showing no choice of substratum. These patterns could be a result of the age of the ARs at these locations. These 2 AR were younger than that at Leucate-Barcarès ( 2 and 5 yr old, respectively, vs. $7 \mathrm{yr}$ old). In fact, several studies have demonstrated that $>10$ yr may be required for an AR to become mature (Bohnsack \& Sutherland 1985, Whitmarsh et al. 2008, Charbonnel \& Bachet 2010). However, domination by sand-preferring species at the Near station of these localities was also found at the NRs, which are mature habitats. This similarity in assemblages between 0 and $1 \mathrm{~km}$ from the ARs was most likely due to parameters other than AR age. At Agde, the lack of any difference could be due to the type (only pipe) and location (200 $\mathrm{m}$ between pipes) of the AR structures. One pipe is a very small structure isolated in a large sandy seascape and cannot attract many individuals. In contrast, at LeucateBarcarès, the 'village' distribution of modules (including 28 modules in an area of $300 \times 400 \mathrm{~m}$ ) attracts more species and a greater abundance of fish. At Agde, the attractiveness of the NR to the fish may be enhanced by the movement of rockpreferring species in response to the greater surface area of hard substratum. The overall area of the natural rocky substrate at Agde is one-third greater than the area of the natural rocky substrate at Leucate-Barcarès. This difference in area was consistent with the difference between the areas of the ARs at the 2 locations (25-fold greater at Agde). Furthermore, it is possible that domination by sand-preferring species at the Agde and Valras ARs was due to limitations of the movement of rock-preferring species. The potential movements of several of these species were restricted because these species will not cross extensive areas of sandy mud (Molles 1978). Thus, it was possible that the domination of sand-preferring species at Agde and Valras was due to the presence of extensive areas of sandy mud between the NRs and the ARs. The movements of rock-preferring species from the NRs to colonize the
ARs could be limited in this context. Furthermore, this flow of potential colonizers toward the ARs could be limited by the main coastal current, which flows from the northeast (Taupier-Letage \& Millot 1986). It is probable that at Agde, if the experimental fishing had been conducted at the AR located to the west of a natural rocky area, an assemblage of rock-preferring species might have been detected at AR-Near. At Valras, it is possible that NR-Near showed an assemblage dominated by sand-preferring species because the natural rocky area has been damaged by illegal trawling. Turner et al. (1999) showed that fishing and habitat degradation could affect the biotic community and shift it toward one that is more typical of a sandy mud bottom.

The species richness and fishing yields were higher at Near stations than at $300 \mathrm{~m}$ from the ARs at Valras and Leucate-Barcarès. These results agree with those reported by Stanley \& Wilson (2000) and Dos Santos et al. (2010), who found a decrease in species richness and number of individuals in the catches with increased distance from the AR to $300 \mathrm{~m}$ and a stabilization at greater distances. Several studies have found a positive link between these variables and the structural complexity of the habitat (Diamant et al. 1986, Carr \& Hixon 1997, Santos et al. 2013). A complex habitat presents many cavities of various sizes and substrate rugosity (Wilson et al. 2007). These parameters increase the number of ecological niches and, thus, the number of species. As complex habitats also provide refuges, fishing pressure is reduced, and fishing yields are greater than on sandy mud bottoms. These various characteristics could be responsible for greater species richness and fishing yields on the ARs of our study. The effect of complexity could explain the finding of this study that fishing yields at Agde were similar at all distances from the ARs. The complexity of a pipe is less than the complexity of a steel cage or of chaotic heaps of material. Thus, the ARs at Agde were less complex than the ARs at Valras and Leucate-Barcarès. The differences in species richness and fishing yields observed for the Valras and Leucate-Barcarès ARs could also have resulted from the lower fishing pressure at Near than at Medium stations. The reason for this difference in fishing pressure is that professional and recreational fishermen prefer to fish outside the boundaries of the ARs rather than inside to avoid the risk of losing their fishing gear (A. Tessier unpubl. data). For B. brandaris and Soleidae, it is possible that the fishing yields were not affected by the distance from the AR because these species do not require a hard substrate. 


\section{ARs vs. NRs}

The ARs supported an assemblage similar to that of the associated NRs at the same study locality except at Leucate-Barcarès. The fish assemblage of the Leucate-Barcarès ARs was dominated by sandpreferring species of commercial interest, whereas the fish assemblage of Leucate-Barcarès NRs was dominated by rock-preferring species of commercial interest. Santos \& Monteiro (1998) stated that if the fish communities of an AR and the associated NR were similar, it would indicate that the fish communities of the study location were in balance. This hypothesis implies that the Agde and Valras ARs reached an ecological balance but that the LeucateBarcarès ARs did not do so. Additional time could be required for the ARs of Leucate-Barcarès to achieve such an ecological balance. However, these ARs might not necessarily support an assemblage similar to that of the NRs of the locality even after a longer time. Andersson \& Ohman (2010) have shown that the fish and invertebrate populations of offshore wind farms (whose structure can be similar to that of an AR) in the Baltic Sea differed from those at adjacent NR locations because the ARs and NRs were not exposed to the same source of colonization, which was linked to larval production. However, it is unlikely that this was the case at Leucate-Barcarès. The coastal current was the same for both the AR and NR at this locality (Taupier-Letage \& Millot 1986). It is probable that the assemblage at the ARs was never similar to the assemblage at the NRs because these 2 habitats did not possess similar structural features (Perkol-Finkel et al. 2006). The species composition at ARs appears to be linked to specific factors, such as (1) the influence of the local NR species composition, as reflected by primary colonization by juveniles or adults (concentration effect), and/or (2) the influence of larvae present in the water mass and moving from a local (auto-recruitment) or offshore location (allo-recruitment). The maintenance of a fish population should be a result of the ecological combination of habitat protection and favorable nutrition. Bohnsack \& Sutherland (1985) have discussed this point in their review of ARs. It is this combination of factors that explains why certain ARs in our study, as well as ARs in other studies, showed assemblages similar to the assemblages of an NR or to a specific assemblage.

ARs appear to be as efficient as NRs because the species assemblages, species richness and fishing yield were similar or better on the ARs. Bohnsack \& Sutherland (1985) and Santos \& Monteiro (2007) reported higher species richness and fishing yields at
ARs than at NRs. Several authors have ascribed this result to the attractive effect of ARs. Cases of similar fishing yields at ARs and NRs are rare in the literature (Bombace et al. 1994, Fujita et al. 1996) because the results are not published if no positive effect is found. Moreover, although the fish catch (in terms of biomass) was greater at the NR than at the AR at Valras, this difference was due to the presence near the NR of large individuals whose commercial value to the artisanal fishermen was low. One-half of these individuals belonged to the family Scorpaenidae.

The finding that at certain localities (in our study, Agde) the ARs showed greater fishing yields than the NR could be linked to the initial objective of the deployment of ARs, namely, their use to prevent illegal trawling. Trawler fishermen avoid ARs because the features of these hard structures can cause fouling of fishing gear and are more likely than NRs to damage a trawl. Additionally, it was possible that this anti-trawling function produced fishing yields of $B$. brandaris and of Soleidae that were greater at the ARs than at the NR for this locality. At the ARs, the stocks of these species of sandy mud bottoms seemed less subject to trawling pressure. This explanation could be verified if a study using multibeam sonar was conducted to show the paths made by trawls on the bottom in the vicinity of the NR and ARs of Agde.

The lack of difference in fishing yields (for all fish considered) between ARs and NRs at certain localities (for example, Leucate-Barcarès or Valras in our study) could be due to a decrease in the efficiency of the ARs. Such a decrease could be the first sign of overfishing. Our study design does not allow further explanations of the similarity in fishing yield between the ARs and NRs. However, it is possible to state that the deployment of ARs created a supplementary fishing site that was similar to the natural fishing site at the same locality. Nevertheless, it was not possible to determine whether ARs could sustain artisanal fishing. It is possible that the natural areas in these particular localities are overexploited. If NRs are overexploited and ARs show fishing yields similar to those of NRs, this similarity would mean that the ARs are already overexploited. In these conditions, ARs cannot serve as a tool to sustain artisanal fishing. However, if NRs are not overexploited and ARs show the same fishing yield as NRs, ARs may be potentially useful for sustaining artisanal fishing by extending the area in which fishing is productive. These characteristics also imply that management is necessary to control fishing activities. To avoid potential overfishing, a limitation of fishing activities around ARs should be enforced. 
For $B$. brandaris and Soleidae, the fishing yields at Valras were higher at the NR than at the AR. It is possible that this difference was due to the composition of the surrounding substrate, which can affect the presence of the prey of these species. B. brandaris prey include bivalves and dead organisms (Ramón \& Amor 2001). The NR is influenced by the input of prey from an alluvial source, the Orb River. However, this source does not contribute prey to the studied AR. It is probable that if the experimental fishing had been conducted at another AR site, the results would have been different because the installation of an AR could modify the local habitat by modifying local currents, thus modifying the soft-bottom species assemblages (Düzbastılar et al. 2006). A difference in granulometry could generate a higher fishing yield of $B$. brandaris and Soleidae in the AR than in the NR at Agde. Granulometry could also explain why the density of Soleidae and $B$. brandaris was lower at Leucate-Barcarès. Nevertheless, it would be necessary to conduct a study of the endofauna of these bottom regions to confirm this possibility.

\section{CONCLUSIONS}

In conclusion, this study showed that the deployment of the studied Languedoc-Roussillon ARs has generated new habitats similar to those of the natural areas for certain localities. The fishing yields of species targeted by trammel nets were similar to these obtained from the local natural areas in the immediate vicinity of the ARs in most cases. Deployed ARs could generate new fishing sites for local fishermen and thus eventually contribute to sustaining artisanal fishing if the sites are not overexploited, if the number of fishermen remains stable and if fishing effort does not increase following the addition of the ARs. However, it is difficult to conclude that ARs are a feasible tool for sustaining fishing yields in this context because it is impossible to say whether the natural areas examined in this study have been overexploited. Another way to demonstrate the effectiveness of ARs would be to follow a BACI-type protocol (Before-After-Control-Impact). With such a protocol, if spatial differences evolve over time, the impact can be attributed to the ARs. In this case, we do not have data from times prior to the installation of ARs at Leucate-Barcarès or Valras. We had such information for Agde, but this information was only obtained from a highly specific sampling method at this site. Furthermore, in France, it is difficult to realize a BACI-type protocol because the AR monitoring was conducted with financial resources provided from the French government or Europe, not from the organization conducting the survey, and generally, these financial resources are not available before AR deployment. Usually, it is necessary to wait for one year after AR deployment to have the financial resources to begin AR monitoring.

Our study appears to have detected a positive effect of ARs on fishing yields, but it is necessary to confirm this finding with long-term monitoring in different seasons. A study of the effect of distance could be used for management of ARs. Given a decrease in yield between 0 and $300 \mathrm{~m}$ or between 0 and $1 \mathrm{~km}$ and the concentrating effect of ARs, a no-take area could be established with a circle of action between 300 and $600 \mathrm{~m}$ around the AR. However, if the AR areas represent a great potential source of harvest for local fisheries, this management strategy would not be viable for the fishermen because their fishing areas would be restricted. An alternative would be fallow rotations: during a specified period, an AR area in the locality would be protected from all human activity. This area would be reopened to human activity following this period, and another AR area of the locality would be closed. To increase efficiency, the closing period of an AR area could last for a longer period, such as 3 yr. Furthermore, it would be appropriate to fix a closing period greater than the opening period. Fallow rotation requires a reflection time, i.e. an experimental phase to know if the rotation would be an appropriate management measure for French ARs. These 2 measures (no-take area and fallow rotation) are only suggestions. Currently in France, in addition to realizing AR monitoring, it will be necessary to undertake an effective AR management plan to maintain the benefits provided by ARs.

Acknowledgements. This work was funded by the Regional Council of Languedoc-Roussillon. A.T. was supported by a doctoral scholarship, CIFRE, from the National Association for Technical Research (ANRT) for SEANEO - UPVD. We thank fishermen G. Berard, J. Rodriguez and E. Berton for conducting the experimental fishing and the staff of UPVDCEFREM-CNRS-UMR 5110 (R. Neveu, A. Caro, G. Perrazio and R. Crec'hriou) for their assistance in data collection.

\section{LITERATURE CITED}

Anderson MJ, Legendre P (1999) An empirical comparison of permutation methods for tests of partial regression coefficients in a linear model. J Statist Comput Simulation 62:271-303

Andersson MH, Ohman MC (2010) Fish and sessile assemblages associated with wind-turbine constructions in the Baltic Sea. Mar Freshw Res 61:642-650 
Barnabé G, Charbonnel E, Marinaro JY, Ody D, Francour P (2000) Artificial reefs in France: analysis, assessments and prospects. In: Jensen AC, Collins KJ, Lockwood AMP (eds) Artificial reefs in European seas. Kluwer Academic, Dordrecht, p 167-184

Bohnsack JA, Sutherland DL (1985) Artificial reef research: a review with recommendations for future priorities. Bull Mar Sci 37:11-39

Bombace G, Fabi G, Fiorentini L, Speranza S (1994) Analysis of the efficacy of artificial reefs located in five different areas of the Adriatic Sea. Bull Mar Sci 55:559-580

Campillo A (1992) Les pêcheries française de Méditérranée: synthèse des connaissances. IFREMER, Sète

Carr MH, Hixon MA (1997) Artificial reefs: the importance of comparisons with natural reefs. Fisheries 22:28-33

Charbonnel E, Bachet F (2010) Artificial reefs in the Cote Bleue Marine Park: assessment after 25 years of experiments and scientific monitoring. In: Ceccaldi HJ, Dekeyser I, Girault M, Stora G (eds) Global change: mankind-marine environment interactions: Proc 13th French-Japanese Oceanogr Symp. Springer, Dordrecht, p 73-79

Colloca F, Crespi V, Cerasi S, Coppola SR (2004) Structure and evolution of the artisanal fishery in a southern Italian coastal area. Fish Res 69:359-369

D'Cruz T, Creech S, Fernandez J (1994) Comparison of catch rates and species composition from artificial and natural reefs in Kerala, India. Bull Mar Sci 55:1029-1037

Diamant A, Tuvia AB, Baranes A, Golani A (1986) An analysis of rocky coastal eastern Mediterranean fish assemblages and a comparison with an adjacent small artificial reef. J Exp Mar Biol Ecol 97:269-285

> Dos Santos LN, Brotto DS, Zalmon IR (2010) Fish responses to increasing distance from artificial reefs on the Southeastern Brazilian Coast. J Exp Mar Biol Ecol 386:54-60

Düzbastılar FO, Lök A, Ula A, Metin C (2006) Recent developments on artificial reef applications in Turkey: hydraulic experiments. Bull Mar Sci 78:195-202

Fabi G, Fiorentini L (1994) Comparison between an artificial reef and a control site in Adriatic Sea: analysis of four years of monitoring. Bull Mar Sci 55:538-558

Fabi G, Sala E (2002) An assessment of biomass and diel activity of fish at an artificial reef (Adriatic sea) using a stationary hydroacoustic technique. ICES J Mar Sci 59: 411-420

FAO (2010) The state of world fisheries and aquaculture. FAO, Rome

> Forcada A, Valle C, Sánchez-Lizaso JL, Bayle-Sempere JT, Corsi F (2010) Structure and spatio-temporal dynamics of artisanal fisheries around a Mediterranean marine protected area. ICES J Mar Sci 67:191-203

Fujita T, Kitagawa D, Okuyama Y, Jin Y, Ishito Y, Inada T (1996) Comparison of fish assemblages among an artificial reef, a natural reef and a sandy-mud bottom site on the shelf off Iwate, northern Japan. Environ Biol Fishes 46:351-364

Gerlotto F, Bercy C, Bordeau B (1989) Echo integration survey around offshore oil extraction platforms off Cameroon: observations of the repulsive effect on fish of some artificially emitted sounds. Proc Inst Acoust 19:79-88

> Gómez S, Lloret J, Demestre M, Riera V (2006) The decline of the artisanal fisheries in Mediterranean coastal areas: the case of Cap de Creus (Cape Creus). Coast Manage 34:217-232

Grossman GD, Jones GP, Seaman W (1997) Do artificial reefs increase regional fish production? A review of existing data. Fisheries 22:17-23

Guillou A, Crespi V (1999) Enquête-Cadre concernant la répartition, la composition et l'activité des petits métiers dans le golfe du Lion. Rapport IFREMER DRV/RH/RST/ 99-14

Harmelin-Vivien ML, Harmelin JG, Chauvet C, Duval C and others (1985) Evaluation visuelle des peuplements et populations de poissons: méthodes et problèmes. Rev Ecol Terre Vie 40:467-539

Heffner RA, Butler MJ, Reilly CK (1996) Pseudoreplication revisited. Ecology 77:2558-2562

IFREMER (2012) Activité 2010 des navires de pêche de la façade Méditerranée. IFREMER

Koeck B, Pastor J, Larenie L, Astruch P, Saragoni G, Jarraya M, Lenfant P (2011) Evaluation of impact of artificial reefs on artisanal fisheries: need for complementary approaches. Braz J Oceanogr 59:1-11

Lebart L, Morineau A, Warwick KM (1984) Multivariate descriptive statistical analysis: correspondence analysis and related techniques for large matrices. Wiley, New York, NY

Leitão F, Santos MN, Erzini K, Monteiro CC (2009) Diplodus spp. assemblages on artificial reefs: importance for near shore fisheries. Fisheries Manag Ecol 16:88-99

Løkkeborg S, Humborstad OB, Jørgensen T, Soldal AV (2002) Spatio-temporal variations in gillnet catch rates in the vicinity of North Sea oil platforms. ICES J Mar Sci 59: S294-S299

Louisy P (2002) Guide d'identifiication des poissons marins Europe de l'ouest et Méditerranée. UMLER, Paris

> Martín P, Sánchez P, Ramón M (1995) Population structure and exploitation of Bolinus brandaris (Mollusca: Gastropoda) off the Catalan coast (northwestern Mediterranean). Fish Res 23:319-331

Matthews KR (1985) Species similarity and movement of fishes on natural and artificial reefs in Monterey Bay, California. Bull Mar Sci 37:252-270

Millar RB, Anderson MJ (2004) Remedies for pseudoreplication. Fish Res 70:397-407

> Molles MC (1978) Fish species diversity on model and natural reef patches: experimental insular biogeography. Ecol Monogr 48:289-305

Ody D (1990) Les récifs artificiels en France. Bilan; analyse; perspectives. Bull Soc Zool Fr 114:49-55

> Osenberg CW, St. Mary CM, Wilson JA, Lindberg WJ (2002) A quantitative framework to evaluate the attractionproduction controversy. ICES J Mar Sci 59:S214-S221

Perkol-Finkel S, Shashar N, Benayahu Y (2006) Can artificial reefs mimic natural reef communities? The roles of structural features and age. Mar Environ Res 61: 121-135

> Pickering H, Whitmarsh D (1997) Artificial reefs and fisheries exploitation: a review of the 'attraction versus production' debate, the influence of design and its significance for policy. Fish Res 31:39-59

Pinnegar JK, Polunin NVC (2004) Predicting indirect effects of fishing in Mediterranean rocky littoral communities using a dynamic simulation model. Ecol Modell 172: 249-267

Polovina JJ (1991) Fisheries applications and biological impacts of artificial habitats. In: Seaman W (eds) Artificial habitats for marine and freshwater fisheries. Academic Press, Waltham, MA, p 153-176

Polovina JJ, Sakai I (1989) Impacts of artificial reefs on fish- 
ery production in Shimamaki, Japan. Bull Mar Sci 44: 997-1003

Ramón M, Amor MJ (2001) Increasing imposex in populations of Bolinus brandaris (Gastropoda: Muricidae) in the north-western Mediterranean. Mar Environ Res 52: $463-475$

Relini M, Torchia G, Relini G (1994) Seasonal variation of fish assemblages in the Loano artificial reef (Ligurian Sea Northwestern-Mediterranean). Bull Mar Sci 52:401-417

Santos MN, Monteiro CC (1997) The Olhão artificial reef system (south Portugal): fish assemblages and fishing yield. Fish Res 30:33-41

Santos MN, Monteiro CC (1998) Comparison of the catch and fishing yield from an artificial reef system and neighbouring areas off Faro (Algarve, south Portugal). Fish Res 39:55-65

Santos MN, Monteiro CC (2007) A fourteen-year overview of the fish assemblages and yield of the two oldest Algarve artificial reefs (southern Portugal). Hydrobiologia 580:225-231

Santos MN, Oliveira MT, Cúrdia J (2013) A comparison of the fish assemblages on natural and artificial reefs off Sal Island (Cape Verde). J Mar Biol Assoc UK 93:437-452

Seaman W (2000) Artificial reef evaluation with application to natural marine habitats. CRC Press, New York, NY

Sokal RR, Rohlf FJ (1995) Biometry: the principals and practice of statistics in biological research. WH Freeman, San Francisco, CA

Editorial responsibility: Christine Paetzold, Oldendorf/Luhe, Germany
Stanley DR, Wilson CA (2000) Variation in the density and species composition of fishes associated with three petroleum platforms using dual beam hydroacoustics. Fish Res 47:161-172

Taupier-Letage I, Millot C (1986) General hydrodynamical features in the Ligurian sea inferred from Dyome experiment. Oceanol Acta 9:119-131

Turner SJ, Thrush SF, Hewitt JE, Cummings VJ, Funnell G (1999) Fishing impacts and the degradation or loss of habitat structure. Fish Manag Ecol 6:401-420

Vasconcelos P, Carvalho S, Castro M, Gaspar MB (2008) The artisanal fishery for muricid gastropods (banded murex and purple dye murex) in the Ria Formosa lagoon (Algarve coast, southern Portugal). Sci Mar 72:287-298

Walton JM (1982) The effects of an artificial reef on resident flatfish populations. Mar Fish Rev 44:45-48

Whitmarsh D, Santos MN, Ramos J, Monteiro CC (2008) Marine habitat modification through artificial reefs off the Algarve (southern Portugal): an economic analysis of the fisheries and the prospects for management. Ocean Coast Manage 51:463-468

Wilson SK, Graham NAJ, Polunin NVC (2007) Appraisal of visual assessments of habitat complexity and benthic composition on coral reefs. Mar Biol 151:1069-1076

> Zalmon IR, Novelli R, Gomes MP, Faria VV (2002) Experimental results of an artificial reef programme on the Brazilian coast north of Rio de Janeiro. ICES J Mar Sci 59:83-87

Submitted: June 10, 2013; Accepted: March 10, 2014

Proofs received from author(s): April 24, 2014 